\title{
Rice cDNA Microarray-Based Gene Expression Profiling of the Response to Flagellin Perception in Cultured Rice Cells
}

\author{
Satsuki Fujiwara, Noriko Tanaka, Takashi Kaneda, Seiji Takayama, Akira Isogai, and Fang-Sik Che \\ Graduate School of Biological Sciences, Nara Institute of Science and Technology (NAIST), 8916-5, Takayama Ikoma, \\ Nara 630-0101, Japan
}

Submitted 8 January 2004. Accepted 5 May 2004.

\begin{abstract}
Incompatible strains of Acidovorax avenae elicit an immune response in cultured rice cells, with immunity specifically induced by the flagellin of the incompatible strain. To identify genes regulated by flagellin perception signaling in cultured rice cells, gene expression patterns were analyzed with rice cDNA microarrays, including 3,353 independent rice cDNA clones. In all, 131 genes were differentially expressed between incompatible and compatible interactions. K-means clustering showed that 94 genes were upregulated and 32 genes were downregulated during incompatible interactions, whereas only 5 genes were upregulated during compatible interactions. Among the 126 genes that were up- or downregulated during incompatible interactions, expression of 46 genes was decreased when cultured rice cells were inoculated with a flagellindeficient incompatible strain $(\Delta$ fla1141-2), indicating that approximately $37 \%$ of the 126 genes were directly controlled by flagellin perception. Real-time reverse-transcription polymerase chain reaction analysis using flagellins purified from incompatible or compatible strains was performed to confirm flagellin-regulated expression of candidate genes selected by microarray analysis. Results showed that induction of some genes involved in the immune response is regulated not only by the flagellin perception pathway, but also by another recognition molecule-perception pathway.
\end{abstract}

Additional keyword: elicitor.

Plants continuously are confronted with diverse potential pathogens, but actual infection occurs only in certain limited cases. In addition to preformed physical and chemical barriers that prevent infection, a wide variety of immune responses are induced only after pathogen attack (Heath 2000). One of the earliest responses activated after host plant recognition is the oxidative burst, in which levels of reactive oxygen species (ROS) rapidly increase (Bolwell et al. 1995; Lamb and Dixon 1997). Other rapid responses include hypersensitive cell death (Greenberg 1997), production of various plant protectants (Dixon et al. 1994), and expression of defense genes (Dixon and Paiva 1995; Zhu et al. 1995). The plant develops resis-

Corresponding author: F. S. Che; Telephone: +81-743-72-5452; Fax: +81743-72-5459; E-mail: fsche@bs.aist-nara.ac.jp

* The $\boldsymbol{e}$-Xtra logo stands for "electronic extra" and indicates the HTML abstract available on-line contains a supplemental table not included in the print edition. tance to pathogen invasion when these immune responses are triggered rapidly and coordinately, whereas susceptible plants activate their immune responses more slowly after infection. Thus, the rapid and effective induction of immune responses appears to be a key difference between resistant and susceptible plants (Keller et al. 1999; Yang et al. 1997).

A key step in induction of immunity is the recognition of pathogen by the plant (Aderem and Ulevitch 2000; Che et al. 1999). Recent studies have identified several specific recognition molecules, called elicitors, such as $\beta$-glucan, chitosan, lipids, and proteins (Boller 1995). Recognition of elicitors by a plant immediately triggers immune responses via a number of signal transduction pathways. A major target of signal transduction is the cell nucleus, where terminal biochemical signals lead to transcriptional activation of numerous genes. Several genes regulated by the recognition signal have been identified from various plant species (Che et al. 2001; Rushton and Somssich 1998). Many of these genes code for various functional proteins, such as enzymes involved in the flow of carbon from primary into secondary metabolism, pathogenesis-related (PR) proteins, transcription factors, and proteins related to signal transduction pathways (Rushton and Somssich 1998). Ordered and harmonic expression of these genes is required for the induction of immunity in plants.

Acidovorax avenae is a gram-negative bacterium that causes a seedling disease characterized by the formation of brown stripes on the sheaths of infected plants (Kadota et al. 1991). The host range of A. avenae is wide among monocotyledonous plants; however, individual strains of the pathogen infect only one or a few host species (Kadota et al. 1991, 1996). We recently reported that a rice-incompatible strain of $A$. avenae causes several immune responses, such as hypersensitive cell death accompanying clear 180-bp nucleosomal DNA laddering and typical morphological change of programmed cell death, $\mathrm{H}_{2} \mathrm{O}_{2}$ generation, and induction of defense genes, whereas the rice-compatible strain of $A$. avenae does not induce these immune response (Che et al. 1999; Iwano et al. 2002; Tanaka et al. 2001, 2003). To identify specific elicitors related to the induction of these immune responses in cultured rice cells, a strain-specific antibody was raised against the incompatible strain (N1141) and then absorbed with the compatible strain (H8301). The specific antibody detected flagellin protein, a component of the flagellum filament of bacteria, which possesses structural differences between compatible and incompatible strains of A. avenae (Che et al. 2000). Flagellin purified from the incompatible strain induced rice immune responses such as hypersensitive cell death, $\mathrm{H}_{2} \mathrm{O}_{2}$ generation, and induction of defense genes in cultured rice cells, whereas flagellin 
purified from the compatible strain induced no responses. Furthermore, a flagellin-deficient N1141 strain lost the ability to induce several immune responses. These data indicate that flagellin from the incompatible strain of $A$. avenae can be characterized as a specific elicitor in immunity in cultured rice cells.

The recently developed cDNA microarray technology allows expression monitoring of hundreds or thousands of genes simultaneously and provides rapid and immediate information for identifying genes (Eisen and Brown 1999; Reymond et al. 2000; Schena et al. 1995). Suspension-cultured cells have the advantage of being relatively homogenous and are useful for profiling short-term gene modification after pathogen or elicitor recognition because all cells are expose by the pathogen or elicitor at the same time (Akimoto-Tomiyama et al. 2003). In addition, our cultured rice cells respond to an incompatible strain of $A$. avenae and the flagellins and have almost complete immune responses. These facts indicate that our experimental systems, which combine cultured rice cells with the $A$. avenae or flagellins, have provided excellent models for studies of the induction mechanism of immune responses in rice. We used cDNA microarrays to identify genes regulated by flagellin recognition and to determine the role of flagellin in induction of immunity. Microarrays were made containing 3,353 independent cDNA clones derived from cDNA libraries prepared from noninoculated cultured rice cells and cells inoculated with an incompatible strain. We first compared gene expression profiles in cultured rice cells during compatible and incompatible interactions to understand the mechanism underlying the rice immune response. We identified 131 genes as being differentially expressed between incompatible and compatible interactions using a statistics calculation method. Among these genes, 94 were specifically upregulated and 32 were downregulated during incompatible interactions. Furthermore, among the incompatible strain-regulated genes, expression variations of 46 genes were decreased when cultured rice cells were inoculated with the flagellin-deficient incompatible strain. The role of flagellin in rice immunity and predicted signaling pathways involved in flagellin perception also are discussed here.

\section{RESULTS}

Profiles of transcript abundance.

A comparison of transcript levels between control and incompatible or compatible interactions was performed to identify transcripts activated during immunity in cultured rice cells. Two cDNA libraries were constructed from cultured rice cells that were either not inoculated (Oc-N0) or inoculated with the incompatible N1141 strain of A. avenae (Oc-N1). From these two cDNA libraries, 2,074 clones from the Oc-N0 library and 2,662 clones from the Oc-N1 library were sequenced, and sequence homologies were found with the GenBank/EMBL database using the FASTA program. cDNAs were classified based on predicted function into 22 categories according to the MIPS Arabidopsis database (MAtDB). Approximately $44 \%$ of the sequences from the Oc-N0 library were unclassified proteins, with unknown function and no homologies. This number was reduced to $38 \%$ in the Oc-N1 library from the incompatible strain-infected cells. More abundant transcripts in the OcN1 library compared with the Oc-N0 library included those involved in energy (4.0 to 5.9\%), transcription (5.4 to $6.6 \%$ ), protein synthesis (10.0 to $12.9 \%$ ), transport facilitation (1.7 to $2.6 \%$ ), and cellular organization (2.2 to $3.3 \%$ ). The functional categories with decreased transcript composition in Oc-N1 cells included metabolism (9.7 to $8.0 \%$ ); cell growth, cell division, and DNA synthesis (2.5 to $1.8 \%$ ); and cellular communication or signal transduction (6.3 to 5.7\%) (Table 1). Sequence and homology analysis revealed that 3,353 cDNA clones were unique (average cDNA size, $1.4 \mathrm{kbp}$ ). These unique cDNAs were used to generate microarrays.

\section{Transcript behavior}

\section{in the incompatible and compatible interactions.}

In all, 3,353 cDNA clones were amplified by polymerase chain reaction $(\mathrm{PCR})$ using primers complementary to vector sequences flanking both sides (see Materials and Methods). Amplified cDNAs were arrayed onto a type 7 star-reflective microarray glass slide. The resulting microarrays comprised 3,353 independent transcripts spotted in duplicate $(6,706$ elements per slide). Microarray analysis was performed twice for

Table 1. Functional categories of transcripts represented in two cDNA libraries ${ }^{\mathrm{a}}$

\begin{tabular}{|c|c|c|c|c|}
\hline \multirow[b]{2}{*}{ Functional categories } & \multicolumn{2}{|c|}{ Oc-NO } & \multicolumn{2}{|c|}{ Oc-N1 } \\
\hline & Number & Percent & Number & Percent \\
\hline Metabolism & 202 & 9.7 & 214 & 8 \\
\hline Energy & 82 & 4 & 156 & 5.9 \\
\hline Cell growth, cell division, and DNA synthesis & 52 & 2.5 & 48 & 1.8 \\
\hline Transcription & 112 & 5.4 & 176 & 6.6 \\
\hline Protein synthesis & 208 & 10 & 344 & 12.9 \\
\hline Protein destination & 65 & 3.1 & 78 & 2.9 \\
\hline Transport facilitation & 35 & 1.7 & 68 & 2.6 \\
\hline Cellular transport and transport mechanisms & 16 & 0.8 & 31 & 1.2 \\
\hline Cellular biogenesis & 32 & 1.5 & 52 & 2 \\
\hline Cellular communication/signal transduction & 130 & 6.3 & 153 & 5.7 \\
\hline Cell rescue, defense, cell death and ageing & 131 & 6.3 & 182 & 6.8 \\
\hline Ionic homeostasis & 0 & 0 & 3 & 0.1 \\
\hline Cellular organization & 46 & 2.2 & 87 & 3.3 \\
\hline Motility & 0 & 0 & 0 & 0 \\
\hline Development & 34 & 1.6 & 37 & 1.4 \\
\hline Transposable elements, viral and plasmid proteins & 6 & 0.3 & 15 & 0.6 \\
\hline Organisms specific proteins & 4 & 0.2 & 7 & 0.3 \\
\hline Classification not yet clear-cut & 0 & 0 & 0 & 0 \\
\hline Unclassified proteins & 4 & 0.2 & 5 & 0.2 \\
\hline Unknown & 452 & 21.8 & 505 & 19 \\
\hline No homology & 461 & 22.2 & 499 & 18.7 \\
\hline None & 2 & 0.1 & 2 & 0.1 \\
\hline Total & 2,074 & 100 & 2,662 & 100 \\
\hline
\end{tabular}

${ }^{a}$ Oc-N0 cDNA library was prepared from uninoculated cultured rice cells, and Oc-N1 cDNA library was prepared from incompatible strain (N1141)inoculated cultured rice cells. 
each experiment using RNAs prepared from three different biological samples. The Cy3/Cy5 signal intensities were adjusted based on the total $\mathrm{Cy} 3$ signal from all spots in relation to the total Cy5 signal. As an initial control, microarray analysis was performed three times with independent microarray slides using Cy3- and Cy5-labeled probes prepared from three different control cultured rice cells (noninfected cells). A total of $88 \%$ of the signals were within \pm 1.5 -fold and $99.0 \%$ of the signals were within \pm 2.0 -fold (data not shown). We concluded, therefore, that our microarrays reliably detected differential gene expression at greater than \pm 2.5 -fold.

To obtain gene expression profiles during incompatible and compatible interactions, cultured rice cells were inoculated with the incompatible N1141 strain or the compatible K1 strain for $0.5,1,2,3,4,5$, and $6 \mathrm{~h}$, and mRNAs from inoculated and control cells (water-treated cells) were used as probes for microarray analysis. In all cases, three independent biological samples were used in separate hybridization. Labeled cDNAs prepared from the cultured rice cells inoculated with either the incompatible or compatible strain were hybridized along with control cDNA prepared from water-treated cultured rice cells. After quantitation of the signal intensities and normalization, we identified genes that showed significant differences in their expression during the compatible and incompatible interactions using multiple testing correction (Benjamini and Hochberg False Discovery Rate, 0.01). In addi- tion, we applied a 2.5 -fold expression cutoff to make the selection more stringent during the compatible and incompatible interactions. Experiments with both types of microarrays led to similar conclusions; therefore, results are presented together. Of 3,353 spotted genes, 798 were selected as responsive to inoculations of incompatible or compatible strains. We next identified genes with differential expression between the incompatible and compatible interactions. A $t$ test revealed that 131 genes were differentially expressed between incompatible and compatible interactions.

\section{Time-specific transcriptional response.}

A K-means clustering was performed to analyze gene expression profiles of 131 genes that were differentially expressed between the incompatible and compatible interactions, and nine clusters could be distinguished (Fig. 1). Among these clusters, clusters $1,2,3,4,5$, and 6 contained genes that were upregulated in the incompatible interaction rather than the compatible interaction (94 genes in all), whereas clusters 7 and 8 contained 5 genes that were upregulated in the compatible interaction rather than the incompatible interaction. Furthermore, cluster 9 contained 32 genes that were downregulated in the incompatible interaction. K-means clustering showed that, among the 131 genes that were differentially expressed between the incompatible and compatible interactions, 126 (97\%) were up- or downregulated during the incompatible interaction.
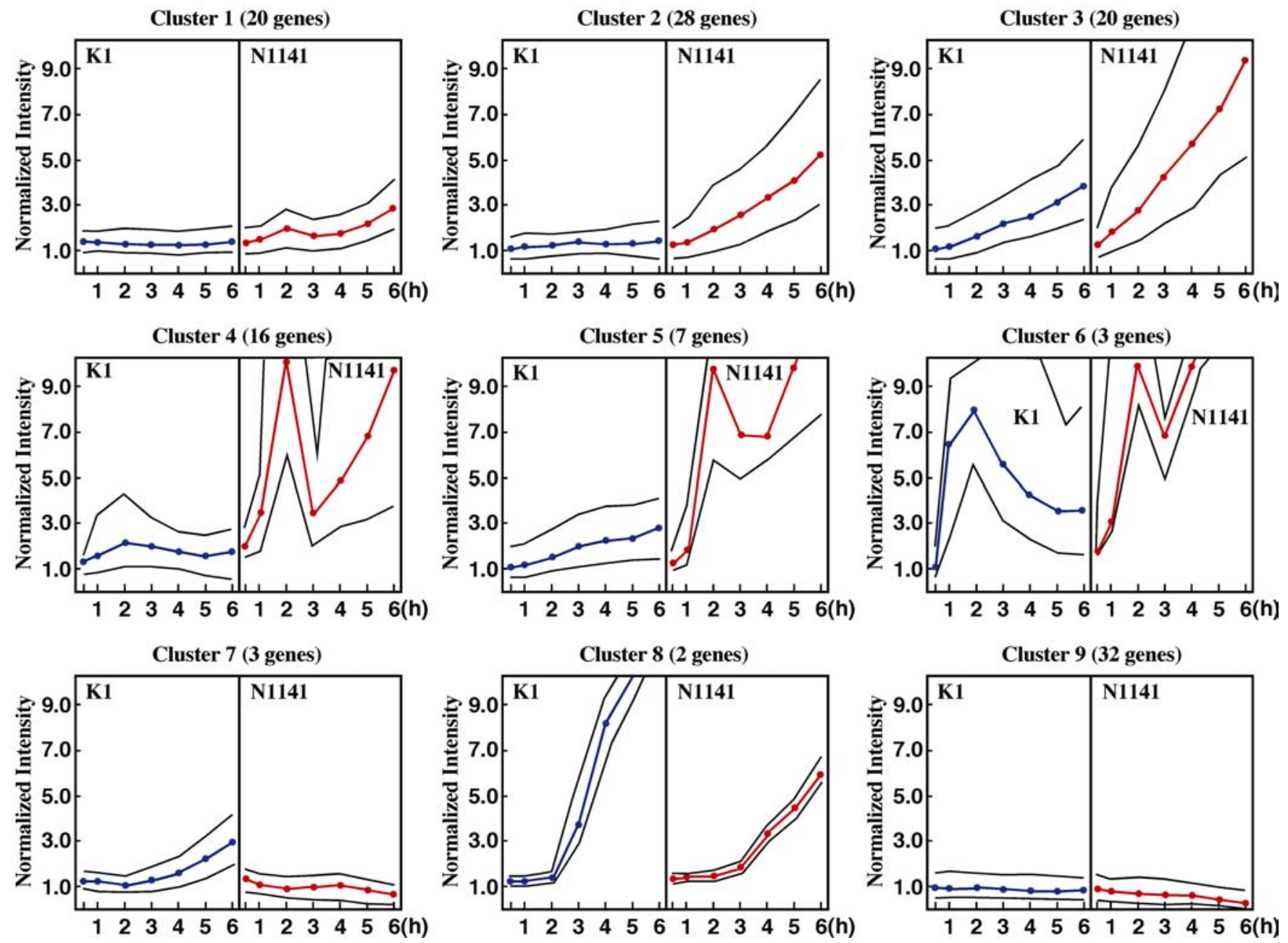

Fig. 1. K-means clustering of expression profiles. Each graph displays the mean pattern of expression (blue line represents K1/water, red line represents N1141/water) of the genes in that cluster and the standard deviation of average expression (black lines). The number of genes in each cluster is at the top center of each graph. The $y$ axis represents normalized gene expression levels. 
The incompatible strain-inducible (ISI) gene clusters (clusters 1 to 6 ) were classified according to predicted function. The most abundant transcripts in the ISI clusters included genes involved in transcription (16.2\%); metabolism $(11.1 \%)$; cellular organization $(10.2 \%)$; signal transduction $(9.4 \%)$; and cell rescue, defense, death, and aging (9.2\%) (Fig. 2). The classification of predicted functions in the ISI clusters was compared with the classification of cDNAs isolated from Oc$\mathrm{N} 0$ and Oc-N1 described in Table 1. In the ISI clusters, the percentage of genes functioning in transcription category was increased 2.6-fold relative to that of the Oc-N0 and Oc-N1 libraries. The protein synthesis category was drastically decreased in the ISI clusters (Fig. 2).

The ISI gene clusters were further categorized into two groups (ISI-A and ISI-B), depending on the pattern of upregulation during incompatible interactions. The ISI-A group contained clusters 1, 2, and 3 and consisted of 68 genes whose expression gradually was increased by inoculation with the incompatible N1141 strain. The ISI-B group contained clusters 4,5 , and 6 , with a relatively small number of genes (26 genes) showing a two-phase induction pattern.

\section{Identification of genes regulated by flagellin perception.}

To identify genes regulated by the flagellin recognition signal pathway, cDNA microarray experiments were performed using the flagellin-deficient N1141 mutant. The flagellin-deficient strain lost the ability to induce several components of the immune response, such as hypersensitive cell death, $\mathrm{H}_{2} \mathrm{O}_{2}$ generation, and some defense gene expression in cultured rice cells (Che et al. 2000; Tanaka et al. 2003). The expression profiles of the 131 genes that were differentially expressed between the incompatible and compatible interactions were analyzed further in cultured rice cells inoculated with the flagellin-deficient $\Delta$ fla1141-2 (Che et al. 1999) strain for 0.5, 1, 2, 3, 4, 5, and $6 \mathrm{~h}$.

Among 131 genes, expression variations of 46 genes were decreased when cultured rice cells were inoculated with the flagellin-deficient $\Delta$ fla1141-2 strain, indicating that expression of these genes was controlled by flagellin perception. In the ISI-A group, 26 genes were identified as flagellin-upregulated genes (Table 2). All of the genes had not been reported previously as incompatible flagellin-controlled genes. These novel transcripts upregulated by the incompatible flagellin included genes with sequence identity with calmodulin-like protein, MAP kinase, thioredoxin, permidase, heat shock protein, Zninduced protein, leucine-rich repeat (LRR)-kinase, N-hydroxycinnamoyl/benzoyltransferase, thaumatin-like protein, UDPgalactose 4-epimerase, cytochrome P450, EDS1, and phosphofructo-1-kinase. Among these genes, the EDS1 homolog (designated OsEDS1:AB118071), which was first identified as a gene required for resistance $(R)$ gene-mediated resistance, was the most highly upregulated. To confirm the expression pattern of $O s E D S 1$, real-time reverse-transcription (RT)-PCR was performed using specific primers. The expression pattern of $O s E D S 1$, as measured by real-time RT-PCR, was almost the same as that obtained by microarray analysis (Fig. 3).

In the ISI-A group, the expression pattern of 42 genes was almost the same between the incompatible N1141 strain and the flagellin-deficient $\Delta$ fla1141-2 strain. Analysis of sequence homology revealed that WRKY (AB117835 and AB117842) and EREBP (AB117844 and AB118068) transcription factors were included in this gene category. It has been known that EREBP (Park et al. 2001; Yang et al. 2002) and WRKY transcription factors play important roles in plant development and in the responses of plants to several stresses (Kim et al. 2000).

The ISI-B group contains 26 transcripts showing two phases of induction. The induction of 18 transcripts was decreased when cultured rice cells were inoculated with $\Delta$ fla1141-2, suggesting that approximately $80 \%$ of the transcripts in this category were involved in flagellin perception signaling. The most abundant functional category within flagellin-upregulated genes in the ISI-B group were transcription factors such as OsNAC3, OsNAC4, myb, and the zinc finger transcription factor ZF1. NAC proteins, such as the petunia NAM and Arabidopsis ATAF1 and $C U C 2$ genes, have NAC domains in their $\mathrm{N}$-terminal region and have been implicated in the regulation of plant development (Duval et al. 2002), wound response, and defense (Collinge and Boller 2001). Our microarray analysis revealed that only three NAC genes, OsNAC3 (AB118092), OsNAC4 (AB118071), and OsNAC6 (AB117820), were upregulated during incompatible interactions. Interestingly, among three NAC genes, induction of $O s N A C 3$ and $O S N A C 4$ was decreased when cultured rice cells were inoculated with the flagellin-deficient $\Delta$ fla1141-2 strain, while OsNAC6 gene induction was retained by the flagellindeficient mutant (Table 2; Fig. 3).

Two important flagellin-upregulated genes involved in calcium signaling were contained in the IAI-B group. The AB118094 gene showed $100 \%$ identity to the rice $\mathrm{Ca}^{2+}$-dependent protein kinase7 (OsCDPK7), and the AB118091 gene showed high homology to wheat $C C D 1$. To test whether $O s C D P K 7$ and $C C D 1$ mRNA expression are regulated by $\mathrm{Ca}^{2+}$, cultured rice cells were inoculated with the incompati-

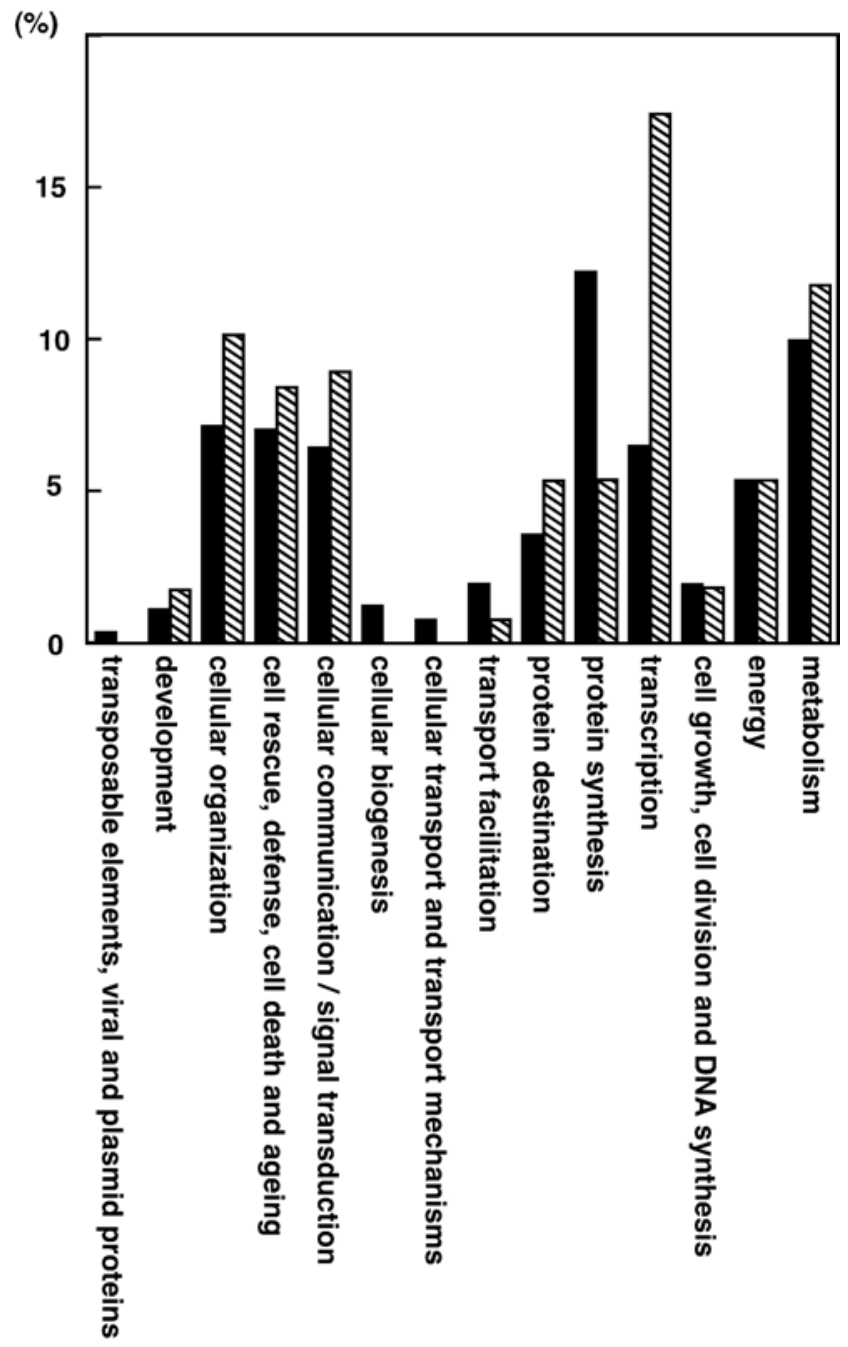

Fig. 2. Comparison of distribution of predicted functions between all 3,353 rice genes on the microarray (striped bar) and the incompatible strain-inducible (ISI cluster) genes (filled bar). 
ble, compatible, and flagellin-deficient strains in the presence of EGTA, and expression patterns were analyzed by real-time RT-PCR (Fig. 4). Chelation of extracellular $\mathrm{Ca}^{2+}$ by EGTA completely blocked the induction of $O s C D P K 7$ and $C C D 1$ expression by incompatible strain inoculation, suggesting that induction of $O s C D P K 7$ was mediated by $\mathrm{Ca}^{2+}$ influx into cultured rice cells and that the calcium signaling pathway is regulated by flagellin perception. In the incompatible interaction between Acidovorax avenae and rice, $\mathrm{Ca}^{2+}$-mediated signaling may be controlled by flagellin perception.

The expression patterns of eight transcripts in the ISI-B group were not affected by inoculation of the flagellin-deficient mutant. These included a Ser/Thr protein kinase, acid phosphate, blue copper protein, and IAI2 Bowman-birk proteinase inhibitor. IAI2 first was identified by a fluorescence differential display in cultured rice cells to identify differentially regulated genes in cells inoculated with either compatible or incompatible strains of A. avenae. IAI2 is a doubleheaded type chymotrypsin inhibitor belonging to the PR protein family and may prevent pathogen infection by proteinase inhibition (Che et al. 2001, 2002).

Cluster 9 contained 32 genes that were reduced during incompatible strain inoculation. Transcripts homologous with ribosomal proteins were most abundant in this category, and we identified five independent transcripts encoding ribosomal proteins. Expression of all genes encoding ribosomal proteins also was reduced when cultured rice cells were inoculated with the flagellin-deficient $\Delta$ fla1141-2 strain, suggesting that reduction of ribosomal proteins genes was not regulated by flagellin. Immune responses induced by the recognition molecules other than flagellin might accompany depression of protein synthesis activity in rice.

\section{Gene expression profile of cultured rice cells treated} with incompatible or compatible flagellins.

To clarify whether the expression of flagellin-regulated genes identified using the flagellin-deficient N1141 mutant also is affected by purified flagellin treatment, real-time RT-PCR analysis was performed using specific primer sets. Purified N1141 and K1 flagellins were added to cultured rice cells and total RNA was extracted $0,0.5,1,2,3,4.5$, and $6 \mathrm{~h}$ after incubation. The OsEDS1 (AB118071) transcript was found to be induced $2 \mathrm{~h}$ after incubation with N1141 flagellin, and expression levels gradually increased up to $6 \mathrm{~h}$ after incubation, whereas mRNA levels of the gene were not increased by treatment with K1 flagellin (Fig. 5). These expression patterns were almost the same as that obtained using the incompatible or the compatible strains (Table 2; Fig. 3), suggesting that induction of
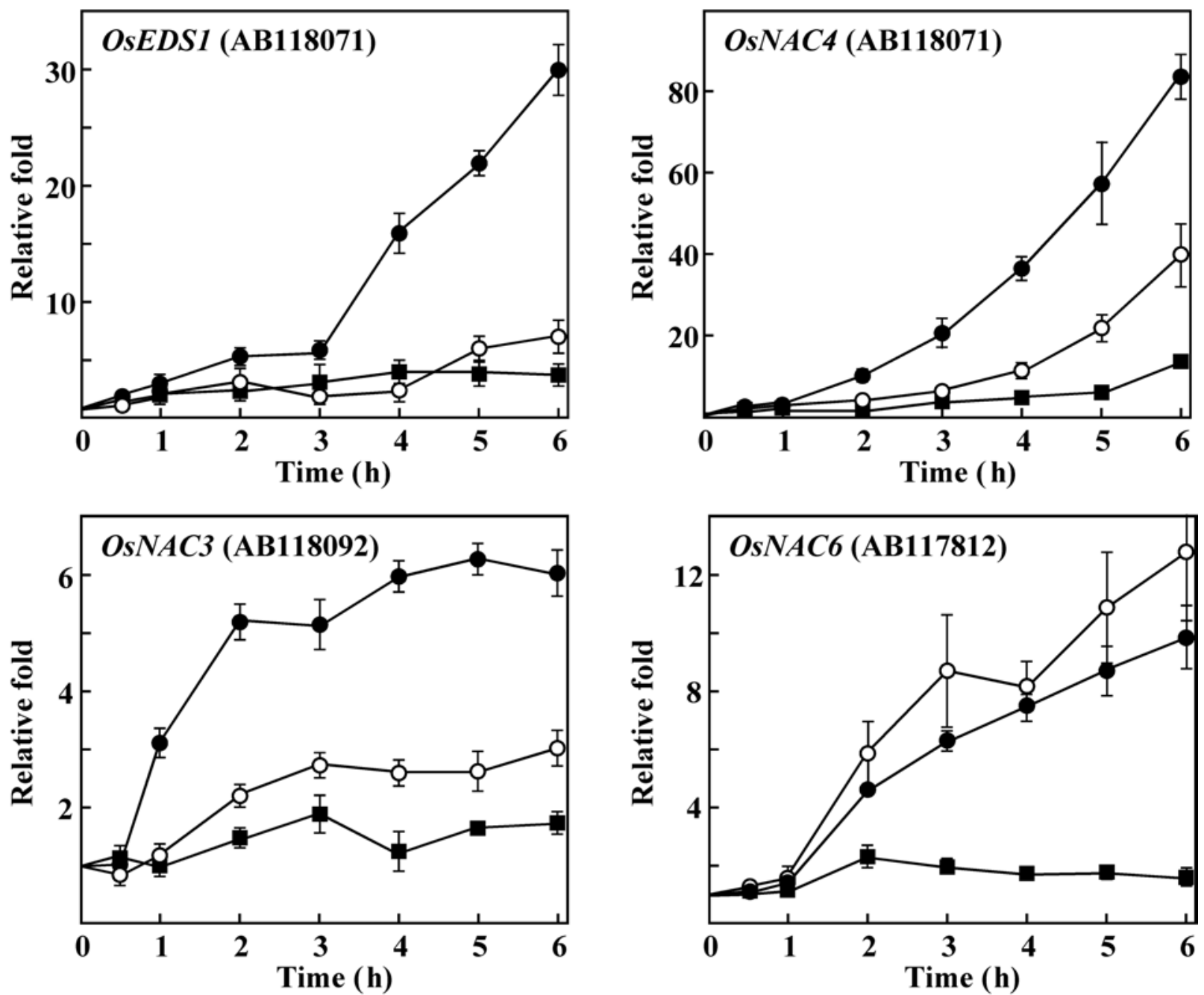

Fig. 3. Expression analysis of OsEDS1 (AB118071), OsNAC3 (AB118092), OsNAC4 (AB118071), and OsNAC6 (AB117812) using real-time reversetranscription polymerase chain reaction (RT-PCR). The amount of each mRNA was calculated from the threshold point located in the log-linear range of RTPCR. Standard samples with known template amounts were used for quantification of each mRNA. Solid circles, N1141 inoculation; open circles, $\Delta$ fla11412 (flagellin-deficient N1141 strain) inoculation; solid squares, K1 inoculation The $y$ axis represents fold change relative to the amount of mRNA in watertreated cultured rice cells. Bars indicate standard deviation of mean of three experiments. 
OsEDS1 by the incompatible strain inoculation was caused by recognition of the flagellin. Two genes involved in calcium signaling, OsCDPK7 (AB118094) and CCD1 (AB118091), were examined next. The expression of these transcripts in cultured rice cells treated with N1141 flagellin showed a two-phase induction pattern (Fig. 5), whereas no significant expression change was observed when cultured rice cells were treated with $\mathrm{K} 1$ flagellin. These data indicate that induction of OsCDPK7 and $C C D 1$ also is controlled by the flagellin-perception signaling. Among NAC transcription factors, OsNAC3 (AB118092), OsNAC4 (AB118071), and OsNAC6 (AB117820) were upregulated during incompatible interaction (Table 2; Fig. 3). Furthermore, the induction of OSNAC3 and OsNAC4 disappeared when cultured rice cells were inoculated with the flagellin-deficient $\Delta$ fla1141-2 mutant, whereas expression of OsNAC6 was induced even with inoculation of the flagellin-deficient mutant (Table 2; Fig. 3). Real-time PCR analysis revealed that OsNAC3 and OsNAC4 mRNAs accumulated after incubation with the N1141 flagellin but not the K1 flagellin (Fig. 5), indicating that induction of these two transcription factors was regulated by flagellin perception. Interestingly, expression of OsNAC6 also was induced by N1141 flagellin treatment. Conflicting results between studies with purified flagellin and the flagellin-deficient $\Delta$ fla1141-2 mutant also were obtained for the WRKY (AB117835) transcription factor and IAI2 (AB118169) genes. The expression of these two genes was induced by inoculation with the flagellin-deficient mutant in the same manner as inocu- lation with the N1141 wild-type strain (Table 2; Fig. 3). However, mRNA accumulation of WRKY and IAI2 also was observed following N1141 flagellin treatment (Fig. 5), whereas K1 flagellin treatment did not affect the expression of these two genes. These data indicate that induction of OsNAC6, WRKY, and IAI2 is regulated not only by the flagellin perception pathway, but also by another elicitor perception pathway. The pattern of induction of EREBP (AB117844) and $m y b$ transcription factor (AB118162) was the same following inoculation with the incompatible N1141 strain and the flagellin-deficient $\Delta$ fla11412 mutant (Table 2; Fig. 3). Real-time PCR analysis using mRNA prepared from cultured rice cells treated with purified N1141 and K1 flagellins showed that neither the incompatible N1141 flagellin nor the compatible $\mathrm{K} 1$ flagellin induced $E R E B P$ and $m y b$ transcription factor expressions (Fig. 5), suggesting that the induction of these two genes is regulated by a flagellinindependent pathway.

\section{DISCUSSION}

In order to identify genes regulated by flagellin perception signaling in cultured rice cells, rice cDNA microarrays containing 3,353 independent cDNA clones were prepared. Because 15,000 individual transcripts are predicted to be present in cultured rice cells, our cDNA microarray covered over $20 \%$ of all transcripts (Ito et al. 1994). The majority of immune-related transcripts, however, should be represented on our microarray

Table 2. Differentially expressed transcripts between cultured rice cells inoculated with the incompatible N1141 and the compatible K1 strains at different time points

\begin{tabular}{|c|c|c|c|c|c|c|c|c|c|c|c|c|c|c|c|c|c|c|c|c|c|c|}
\hline \multirow[b]{2}{*}{ Accession $^{a}$} & \multirow[b]{2}{*}{ Putative gene identification } & \multicolumn{7}{|c|}{ N1141 } & \multicolumn{7}{|c|}{ K1 } & \multicolumn{7}{|c|}{$\Delta$ flaN1141-2 } \\
\hline & & $0.5^{\mathrm{b}}$ & 1 & 2 & 3 & 4 & 5 & 6 & 0.5 & 1 & 2 & 3 & 4 & 5 & 6 & 0.5 & 1 & 2 & 3 & 4 & 5 & 6 \\
\hline Cluster1 & & & & & & & & & & & & & & & & & & & & & & \\
\hline AB 117864 & Unknown & 1.5 & 2.0 & 2.8 & 2.9 & 3.3 & 3.4 & 3.2 & 1.6 & 2.0 & 1.9 & 2.0 & 1.8 & 1.7 & 1.6 & 1.7 & 2.1 & 2.3 & 3.1 & 2.7 & 3.5 & 3.4 \\
\hline $\mathrm{AB} 117865$ & Unknown & 1.6 & 1.7 & 2.6 & 2.0 & 2.3 & 2.8 & 3.3 & 1.7 & 1.6 & 1.7 & 1.6 & 1.7 & 1.8 & 1.9 & 1.8 & 1.7 & 2.2 & 2.7 & 2.6 & 2.7 & 4.0 \\
\hline $\mathrm{AB} 117867$ & No homology & 1.5 & 1.8 & 2.2 & 1.9 & 2.0 & 2.4 & 3.0 & 1.5 & 1.9 & 2.0 & 1.8 & 1.3 & 1.4 & 1.2 & 1.5 & 2.0 & 2.3 & 2.5 & 2.2 & 2.6 & 2.8 \\
\hline AB 117868 & Unknown & 1.6 & 1.4 & 1.9 & 1.8 & 2.0 & 2.2 & 3.0 & 1.5 & 1.6 & 1.5 & 1.4 & 1.5 & 1.5 & 1.8 & 1.7 & 1.6 & 1.7 & 2.3 & 1.9 & 2.1 & 2.5 \\
\hline AB 117869 & No homology & 1.7 & 1.5 & 2.0 & 2.0 & 1.8 & 2.9 & 2.6 & 1.3 & 1.3 & 1.4 & 1.6 & 1.6 & 1.7 & 1.9 & 1.6 & 1.4 & 1.8 & 1.8 & 1.9 & 2.0 & 2.4 \\
\hline $\mathrm{AB} 117857$ & $\mathrm{~B} 12 \mathrm{D}$ & 1.4 & 1.8 & 2.4 & 2.3 & 2.3 & 2.5 & 3.0 & 1.3 & 1.4 & 1.6 & 1.7 & 1.7 & 1.6 & 1.5 & 1.4 & 1.3 & 1.8 & 2.1 & 2.3 & 2.3 & 2.7 \\
\hline $\mathrm{AB} 117870$ & No homology & 1.7 & 1.9 & 2.0 & 2.1 & 2.7 & 3.2 & 3.1 & 1.6 & 1.5 & 1.6 & 1.6 & 1.6 & 1.5 & 1.7 & 1.6 & 1.5 & 1.7 & 2.2 & 2.3 & 2.6 & 2.8 \\
\hline AB 117871 & No homology & 1.2 & 1.3 & 1.3 & 1.6 & 1.7 & 2.6 & 3.3 & 1.3 & 1.3 & 1.4 & 1.4 & 1.5 & 1.3 & 1.6 & 1.3 & 1.2 & 1.4 & 1.5 & 1.6 & 2.0 & 2.3 \\
\hline $\mathrm{AB} 117872$ & Blue copper binding protein & 1.7 & 3.3 & 4.4 & 4.2 & 5.4 & 4.2 & 4.3 & 1.8 & 2.9 & 3.5 & 2.1 & 1.7 & 1.3 & 1.6 & 1.8 & 3.9 & 5.3 & 8.0 & 6.2 & 6.8 & 6.9 \\
\hline AB 117876 & Cinnamyl alcohol dehydrogense & 1.6 & 1.9 & 2.5 & 3.0 & 3.2 & 2.8 & 3.4 & 1.4 & 1.3 & 1.8 & 2.1 & 1.6 & 1.3 & 1.4 & 1.7 & 1.6 & 2.0 & 3.0 & 3.2 & 2.9 & 3.0 \\
\hline $\mathrm{AB} 117880$ & Protein phosphatase 1 & 1.3 & 1.4 & 1.6 & 1.5 & 1.4 & 2.3 & 2.5 & 1.2 & 1.2 & 1.3 & 1.3 & 1.1 & 1.2 & 1.3 & 1.3 & 1.4 & 1.6 & 1.8 & 1.7 & 2.2 & 2.4 \\
\hline $\mathrm{AB} 117882 \%$ & No homology & 1.5 & 1.6 & 2.4 & 1.8 & 2.4 & 3.5 & 4.0 & 1.5 & 1.4 & 1.6 & 1.3 & 1.7 & 1.4 & 1.6 & 1.5 & 2.0 & 2.2 & 2.0 & 1.9 & 1.8 & 1.8 \\
\hline $\mathrm{AB} 117889 \%$ & Calmodulin-like protein & 1.8 & 2.0 & 2.3 & 2.1 & 2.3 & 3.5 & 4.5 & 1.7 & 1.7 & 1.6 & 1.5 & 1.6 & 1.8 & 1.9 & 1.7 & 1.9 & 1.9 & 1.8 & 1.8 & 2.0 & 1.9 \\
\hline $\mathrm{AB} 117890$ & Unknown & 1.8 & 2.0 & 2.0 & 2.4 & 2.9 & 3.2 & 3.5 & 1.8 & 1.9 & 1.7 & 2.0 & 2.1 & 2.0 & 1.9 & 1.6 & 1.9 & 2.1 & 2.5 & 3.1 & 3.3 & 3.2 \\
\hline AB117887 & PGPS/D12 & 1.4 & 1.3 & 1.8 & 1.5 & 1.4 & 2.8 & 2.8 & 1.3 & 1.1 & 1.5 & 1.4 & 1.3 & 1.6 & 1.5 & 1.3 & 1.4 & 1.6 & 1.6 & 1.8 & 2.2 & 2.8 \\
\hline $\mathrm{AB} 117810 *$ & Unknown & 1.5 & 1.6 & 2.2 & 2.4 & 2.3 & 2.6 & 3.3 & 1.4 & 1.2 & 1.3 & 1.6 & 1.9 & 1.8 & 1.9 & 1.3 & 1.3 & 1.5 & 1.5 & 1.9 & 2.2 & 2.4 \\
\hline $\mathrm{AB} 117859$ & POU-box prot & 1.3 & 1.4 & 1.5 & 1.5 & 1.5 & 2.3 & 2.5 & 1.2 & 1.2 & 1.3 & 1.3 & 1.2 & 1.4 & 1.6 & 1.2 & 1.3 & 1.4 & 1.6 & 1.4 & 2.0 & 2.3 \\
\hline $\mathrm{AB} 117860$ & Glycine and proline-rich protein & 1.6 & 1.4 & 3.0 & 2.9 & 1.9 & 2.2 & 2.5 & 1.5 & 1.3 & 1.6 & 1.7 & 1.5 & 1.0 & 0.8 & 1.6 & 1.8 & 1.8 & 1.6 & 2.1 & 3.0 & 2.8 \\
\hline $\mathrm{AB} 117861 *$ & Unknown & 1.4 & 1.3 & 1.2 & 1.6 & 1.7 & 2.0 & 3.0 & 1.2 & 1.1 & 1.0 & 1.2 & 1.1 & 1.2 & 1.8 & 1.1 & 1.1 & 1.0 & 1.0 & 1.1 & 1.4 & 1.4 \\
\hline $\begin{array}{r}\mathrm{AB} 117862 \\
\text { Cluster2 }\end{array}$ & No homology & 1.4 & 1.8 & 2.2 & 2.0 & 2.4 & 2.5 & 2.6 & 1.4 & 1.5 & 1.8 & 1.6 & 1.5 & 1.7 & 1.6 & 1.4 & 1.8 & 2.6 & 4.0 & 3.2 & 3.3 & 3.3 \\
\hline $\mathrm{AB} 117830$ & GDP fucose synthase & .9 & 2.0 & 3.1 & 4.1 & 4.2 & 4.6 & 4.7 & 1.9 & 1.8 & 3.5 & 4.0 & 2.8 & 2.4 & 2.0 & 1.9 & 1.9 & 4.5 & 4.9 & 6.5 & 6.2 & 6.0 \\
\hline $\mathrm{AB} 117817$ & Glycosyl transferase & 1.8 & 1.8 & 3.4 & 1.8 & 2.7 & 4.3 & 4.2 & 1.5 & 1.9 & 1.6 & 1.7 & 1.5 & 1.7 & 1.5 & 1.8 & 2.6 & 1.9 & 2.1 & 2.0 & 4.1 & 3.0 \\
\hline $\mathrm{AB} 117831$ & Glutamyl-tRN & 1.0 & 1.2 & 1.1 & 1.2 & 1.0 & 2.4 & 6.3 & 0.9 & 0.8 & 1.0 & 1.1 & 0.8 & 0.9 & 1.1 & 1.2 & 0.9 & 0.8 & 1.0 & 0.8 & 1.5 & 4.0 \\
\hline $\mathrm{AB} 117818$ & No homology & 1.1 & 1.0 & 1.4 & 1.6 & 1.8 & 2.9 & 2.4 & 1.0 & 0.9 & 1.2 & 1.3 & 1.6 & 1.2 & 1.1 & 1.2 & 1.0 & 1.0 & 1.3 & 2.2 & 2.0 & 2.3 \\
\hline $\mathrm{AB} 117819$ & Amino acid permease & 1.2 & 1.3 & 2.2 & 2.8 & 2.7 & 3.3 & 4.8 & 1.3 & 1.2 & 1.9 & 2.3 & 1.6 & 1.9 & 1.9 & 1.3 & 1.5 & 2.0 & 2.3 & 2.0 & 2.2 & 3.6 \\
\hline $\mathrm{AB} 117820$ & OsNAC6 protein & 1.3 & 1.2 & 2.5 & 1.8 & 2.2 & 2.6 & 4.0 & 1.2 & 1.0 & 1.6 & 1.6 & 1.5 & 1.8 & 2.2 & 1.1 & 1.1 & 2.2 & 2.4 & 2.1 & 2.6 & 3.6 \\
\hline $\mathrm{AB} 117833$ & Unknown & 1.9 & 1.8 & 3.8 & 3.8 & 4.4 & 5.1 & 5.0 & 1.8 & 1.8 & 2.5 & 2.9 & 2.3 & 2.0 & 2.1 & 1.8 & 1.8 & 2.6 & 3.4 & 3.5 & 4.3 & 4.8 \\
\hline $\mathrm{AB} 117812$ & OsNAC6 protein & 1.1 & 1.4 & 3.3 & 3.2 & 3.6 & 5.6 & 5.3 & 1.4 & 1.2 & 1.9 & 2.4 & 2.1 & 2.5 & 3.0 & 1.8 & 1.4 & 2.5 & 3.3 & 2.8 & 4.6 & 5.3 \\
\hline $\mathrm{AB} 117835$ & WRKY DNA binding protein & 1.9 & 2.2 & 3.9 & 3.3 & 3.8 & 4.7 & 5.4 & 1.8 & 2.2 & 2.5 & 2.4 & 2.6 & 1.9 & 2.8 & 1.8 & 2.6 & 3.3 & 4.1 & 2.9 & 4.4 & 4.7 \\
\hline $\mathrm{AB} 117837$ & Unknown & 1.7 & 2.4 & 3.5 & 3.3 & 5.9 & 5.2 & 4.8 & 1.9 & 2.5 & 2.5 & 2.1 & 1.9 & 1.8 & 2.2 & 1.9 & 3.5 & 2.9 & 5.5 & 4.7 & 6.0 & 5.0 \\
\hline $\mathrm{AB} 117838$ & Unknown & 2.0 & 2.6 & 3.7 & 3.6 & 6.2 & 8.6 & 6.6 & 1.9 & 2.4 & 2.8 & 2.3 & 2.3 & 2.7 & 2.5 & 1.8 & 2.6 & 3.5 & 5.4 & 4.6 & 7.4 & 6.3 \\
\hline AB 117839 & Phosphoserine aminotransferase & 1.6 & 1.1 & 1.5 & 3.3 & 2.8 & 2.9 & 3.2 & 1.5 & 1.2 & 1.5 & 2.7 & 2.6 & 1.5 & 1.5 & 1.5 & 1.1 & 1.8 & 2.3 & 3.0 & 2.5 & 2.4 \\
\hline $\mathrm{AB} 117851 \%$ & MAP kinase protein for Oryza sativa & 1.0 & 0.9 & 1.3 & 2.3 & 5.0 & 6.7 & 6.2 & 0.9 & 1.0 & 1.0 & 1.5 & 2.1 & 2.0 & 2.2 & 0.9 & 1.0 & 1.1 & 1.5 & 2.1 & 2.6 & 2.5 \\
\hline $\mathrm{AB} 117827$ & No homology & 1.2 & 1.3 & 2.1 & 3.8 & 4.5 & 4.2 & 4.0 & 1.2 & 1.3 & 1.4 & 1.7 & 2.0 & 1.7 & 1.5 & 1.3 & 1.5 & 1.5 & 4.0 & 8.0 & 7.9 & 8.8 \\
\hline
\end{tabular}

\footnotetext{
a Transcripts indicated by as asterisk $(*)$ are regulated by flagellin recognition signaling.

b Time points are indicated in hours.
} 
because it was prepared from cDNA libraries derived from noninoculated cultured rice cells and cells inoculated with an incompatible strain. In all, 131 genes were differentially expressed between incompatible and compatible interactions within $6 \mathrm{~h}$ after inoculation. Our cDNA microarray analysis suggests that the number of genes involved in early stages of immune system induction is comparatively small, and that induction of drastic early events during the immune response may result from the expression of relatively few genes.

cDNA microarray technology allows the determination of transcript abundance by comparing control and experimental states. With appropriate controls and repeat experiments, data can be obtained on gene expression profiles under various conditions. However, cDNA microarray data is not sufficient for determining genes with significant expression alterations because analysis of cDNA microarray data usually uses automatic cut-offs and statistical calculations. In addition, cross hybridization of highly homologous genes may impede the determination of an accurate expression profile of a given gene. A combination of microarrays and other modalities may be necessary to obtain highly accurate transcriptome data. Therefore, real-time RT-PCR analysis was used to confirm the expression profile of a number of significant genes.

cDNA microarrays in combination with real-time RT-PCR analysis identified a number of genes regulated by flagellin perception signaling. Among these genes, the OsEDS1 tran- script was one of the most highly upregulated by incompatible flagellin (Table 2; Figs. 3 and 5). EDS1 first was identified in Arabidopsis thaliana as a gene required for $R$-gene mediated resistance (Falk et al. 1999). Inoculation of $A$. thaliana Landsberg-erecta (Ler, expressing RPS4) with a virulent Pseudomonas syringae DC3000 strain did not induce EDS1 mRNA expression, whereas inoculation with an avirulent DC3000 strain expressing avrRps 4 drastically induced EDS1 expression after 6 h. Mutations in EDS1 abolished RPS4-mediated resistance in Ler to $P$. syringae expressing avrRps4. The EDS1 mutation also suppressed $R$ gene-mediated resistance to several other pathogens. Although the function of $O s E D S 1$ still is not clear, this gene is now a candidate for regulating signaling pathways involved in flagellin perception.

cDNA microarrays in combination with real-time RT-PCR analysis demonstrated that expression levels of several transcription factors were altered in cultured rice cells in response to flagellin perception. OsNAC is one of the most abundant transcription factors. NAC proteins, such as the petunia NAM and Arabidopsis ATAF1 and CUC2 genes, have NAC domains in their $\mathrm{N}$-terminal region and have been implicated in the regulation of plant development (Duval et al. 2002), wound response, and defense (Collinge and Boller 2001). Our analysis revealed that three NAC genes, OsNAC3 (AB118092), OsNAC4 (AB118071), and OsNAC6 (AB117812 and AB117820), were upregulated during the incompatible interaction. Interestingly,

Table 2. (continued from preceding page)

\begin{tabular}{|c|c|c|c|c|c|c|c|c|c|c|c|c|c|c|c|c|c|c|c|c|c|c|}
\hline \multirow[b]{2}{*}{ Accession } & \multirow[b]{2}{*}{ Putative gene identification } & \multicolumn{7}{|c|}{ N1141 } & \multicolumn{7}{|c|}{$\mathrm{K} 1$} & \multicolumn{7}{|c|}{$\Delta$ flaN1141-2 } \\
\hline & & 0.5 & 1 & 2 & 3 & 4 & 5 & 6 & 0.5 & 1 & 2 & 3 & 4 & 5 & 6 & 0.5 & 1 & 2 & 3 & 4 & 5 & 6 \\
\hline Cluster2 & (Continued) & & & & & & & & & & & & & & & & & & & & & \\
\hline AB 117842 & WRKY DNA binding protein & 2.0 & 2.7 & 5.3 & 4.2 & 5.5 & 6.9 & 9.0 & 2.0 & 2.7 & 3.2 & 3.1 & 3.3 & 2.5 & 3.6 & 2.0 & 3.5 & 4.2 & 5.6 & 4.6 & 6.8 & 7.5 \\
\hline AB117814 & Symbiosys-related protein & 1.4 & 1.6 & 4.1 & 4.0 & 6.5 & 6.2 & 5.2 & 1.6 & 2.5 & 3.0 & 2.2 & 2.1 & 1.4 & 1.9 & 1.3 & 2.8 & 5.7 & 6.0 & 4.5 & 5.6 & 4.6 \\
\hline AB117844 & Transcription & 1.0 & 1.1 & 1.3 & 2.5 & 3.3 & 2.8 & 2.7 & 1.0 & 1.2 & 1.3 & 1.5 & 1.9 & 1.3 & 1.5 & 1.2 & 1.3 & 1.4 & 1.9 & 2.7 & 2.3 & 2.4 \\
\hline AB117845 & Proteasome & 0.9 & 1.0 & 0.9 & 1.7 & 2.5 & 3.2 & 3.0 & 0.8 & 0.8 & 0.8 & 1.1 & 1.5 & 1.5 & 1.7 & 0.9 & 1.0 & 0.7 & 1.0 & 2.3 & 2.3 & 2.7 \\
\hline AB117848* & No hon & 1.0 & 0.9 & 1.3 & 1.3 & 2.2 & 3.0 & 3.1 & 0.9 & 0.8 & 0.8 & 1.2 & 1.3 & 1.2 & 1.2 & 0.9 & 0.9 & 0.8 & 1.3 & 1.6 & 2.0 & 2.5 \\
\hline AB 117849 & Unkno & 1.2 & 1.3 & 2.4 & 2.0 & 1.8 & 3.0 & 3.3 & 1.2 & 1.3 & 1.4 & 1.4 & 1.2 & 1.7 & 1.5 & 1.3 & 1.5 & 1.7 & 2.2 & 2.1 & 3.2 & 3.1 \\
\hline AB 117855 & GTP & 1.4 & 1.6 & 4.5 & 4.4 & 6.8 & 6.9 & 6.7 & 1.3 & 2.0 & 3.1 & 3.2 & 2.7 & 2.0 & 2.3 & 1.4 & 2.3 & 3.5 & 4.0 & 4.7 & 5.4 & 6.0 \\
\hline AB117816* & Unkno & 1.3 & 1.3 & 1.7 & 1.6 & 2.2 & 2.6 & 3.0 & 1.2 & 1.1 & 1.2 & 1.0 & 1.3 & 1.3 & 1.4 & 1.3 & 1.4 & 1.3 & 1.5 & 1.6 & 2.1 & 2.6 \\
\hline AB $117825^{*}$ & Thior & 1.1 & 0.9 & 1.0 & 1.6 & 1.9 & 2.5 & 3.8 & 1.1 & 1.2 & 1.0 & 1.1 & 1.2 & 1.1 & 1.2 & 1.1 & 0.8 & 1.0 & 1.1 & 1.5 & 1.5 & 1.8 \\
\hline $\mathrm{AB} 11$ & ssociated protein & 1.6 & 1.4 & 2.5 & 3.0 & 4.1 & 3.8 & 4.0 & 1.6 & 1.4 & 1.3 & 2.0 & 2.2 & 1.9 & 2.1 & 1.5 & 1.4 & 1.5 & 2.9 & 3.4 & 3.8 & 4.5 \\
\hline $\mathrm{AB} 11$ & No $h$ & 1.5 & 1.3 & 2.1 & 2.7 & 3.7 & 3.3 & 3.8 & 1.5 & 1.4 & 1.4 & 1.8 & 2.3 & 1.9 & 1.7 & 1.6 & 1.3 & 1.6 & 2.6 & 3.2 & 3.5 & 4.2 \\
\hline $\mathrm{AB} 11$ & Unk & 2 & 4.4 & 2.4 & 1.7 & 3.6 & 3.0 & 4.5 & 1.2 & 1.3 & 1.4 & 2.0 & 1.5 & 1.5 & 1.6 & 1.2 & 1.3 & 2.0 & 2.6 & 2.2 & 2.7 & 2.5 \\
\hline $\mathrm{AB} 11$ & Perm & 1.4 & 1.5 & 2.6 & 2.6 & 3.3 & 4.0 & 4.1 & 1.2 & 1.2 & 1.0 & 1.6 & 1.9 & 1.8 & 2.2 & 1.2 & 1.3 & 1.2 & 1.3 & 1.5 & 1.8 & 1.7 \\
\hline $\begin{array}{c}\text { AB 1 17824* } \\
\text { Cluster3 }\end{array}$ & & 1.5 & 1.6 & 2.0 & 2.1 & 3.0 & 3.1 & 3.3 & 1.5 & 1.7 & 1.8 & 1.7 & 1.8 & 1.6 & 1.9 & 1.5 & 1.6 & 1.9 & 1.9 & 1.7 & 1.7 & 2.0 \\
\hline AB 1 18078* & No & 1. & 1.4 & 2.4 & 3.4 & 5.0 & 8.3 & 9.0 & 1.3 & 1.4 & 1.1 & 2.0 & 3.1 & 4.2 & 4.5 & 1.3 & 1.2 & 1.3 & 1.9 & 2.1 & 3.0 & 3.4 \\
\hline & & & 1.4 & 1.4 & 3.4 & 3.4 & 4.7 & 7.1 & 1.4 & 1.3 & 1.6 & 2.2 & 2.9 & 2.6 & 3.1 & 1.4 & 1.4 & 1.6 & 1.9 & 3.0 & 2.8 & 4.1 \\
\hline & $\mathrm{Zn}-$ & 4 & 1.4 & 2.7 & 3.0 & 5.0 & 6.7 & 9.0 & 1.3 & 1.5 & 1.4 & 2.0 & 2.7 & 3.6 & 3.1 & 1.3 & 1.3 & 1.5 & 1.8 & 2.1 & 3.1 & 3.4 \\
\hline & O.s & 3 & 1.2 & 1.2 & 2.3 & 3.0 & 4.2 & 5.0 & 1.3 & 1.2 & 1.4 & 1.6 & 1.8 & 2.5 & 3.0 & 1.3 & 1.2 & 1.4 & 1.4 & 2.1 & 2.0 & 2.0 \\
\hline & No & 2 & 1.0 & 2.2 & 3.2 & 6.3 & 5.3 & 6.1 & 1.2 & 1.2 & 1.2 & 2.6 & 3.1 & 2.8 & 1.8 & 1.2 & 1.3 & 1.4 & 2.6 & 3.2 & 3.6 & 3.5 \\
\hline & Unk & 2 & 1.3 & 1.9 & 2.8 & 2.9 & 6.0 & 9.9 & 1.3 & 1.2 & 1.4 & 1.4 & 1.7 & 1.4 & 3.3 & 1.3 & 1.7 & 1.3 & 1.5 & 1.7 & 2.6 & 3.4 \\
\hline & $\mathrm{Zn}-\mathrm{i}$ & 1.3 & 1.5 & 2.2 & 2.4 & 3.7 & 5.0 & 7.1 & 1.2 & 1.3 & 1.3 & 1.7 & 2.4 & 3.0 & 3.2 & 1.2 & 1.3 & 1.3 & 1.7 & 1.8 & 2.3 & 2.6 \\
\hline $\mathrm{AB} 1$ & $\begin{array}{r}\text { N-hydroxyc } \\
\text { benzoyltr }\end{array}$ & 1.1 & 0.9 & 1.8 & 3.0 & 2.6 & 3.0 & 4.1 & 1.1 & 0.9 & 1.2 & 1.6 & 1.6 & 1.6 & 1.7 & 1.1 & 0.9 & 1.4 & 1.6 & 1.9 & 2.1 & 2.5 \\
\hline & Tha & 1.6 & 1.5 & 1.9 & 3.0 & 4.6 & 5.4 & 9.0 & 1.6 & 1.5 & 1.6 & 2.1 & 2.1 & 2.2 & 2.9 & 1.5 & 1.4 & 1.5 & 1.9 & 2.0 & 3.0 & 4.1 \\
\hline $\mathrm{AB} 1$ & UD & 1.6 & 1.5 & 1.9 & 2.9 & 4.4 & 5.0 & 8.1 & 1.5 & 1.4 & 1.3 & 1.9 & 2.6 & 2.5 & 2.4 & 1.5 & 1.4 & 1.3 & 1.8 & 1.9 & 2.1 & 2.2 \\
\hline $65^{*}$ & Cyt & 1.4 & 1.4 & 2.0 & 4.0 & 4.2 & 15.2 & 19.9 & 1.4 & 1.3 & 1.5 & 2.9 & 3.7 & 6.6 & 9.2 & 1.3 & 1.5 & 1.5 & 2.3 & 2.0 & 4.6 & 5.8 \\
\hline & $\mathrm{Ami}$ & 2.0 & 4.2 & 7.3 & 7.9 & 14.5 & 21.0 & 19.3 & 2.2 & 5.0 & 10.5 & 5.7 & 6.4 & 4.0 & 3.3 & 1.9 & 6.0 & 16.6 & 15.6 & 22.2 & 20.0 & 23.0 \\
\hline & & 1 & 1.5 & 3.1 & 4.6 & 8.0 & 11.1 & 13.3 & 1.4 & 1.4 & 1.6 & 3.5 & 3.1 & 3.0 & 3.1 & 1.5 & 1.4 & 1.4 & 2.5 & 2.8 & 3.1 & 3.5 \\
\hline & & & 1.6 & 2.4 & 1.5 & 4.0 & 5.4 & 5 . & 1.1 & 1.5 & 1.5 & 1.5 & 1.4 & 1.4 & 1.5 & 1.2 & 2.3 & 1.6 & 2.3 & 1.9 & 4.8 & 6.0 \\
\hline & & & 1.1 & 1.0 & 2.6 & 2.7 & 6.0 & 8.0 & 1.2 & 1.0 & 1.1 & 1.7 & 1.5 & 1.8 & 2.4 & 1.2 & 0.9 & 1.0 & 2.0 & 2.8 & 3.8 & 7.1 \\
\hline & & 1. & 2.2 & 4.8 & 3.1 & 16.1 & 22.6 & 32.2 & 1.5 & 2.3 & 1.9 & 2.4 & 5.1 & 5.9 & 6.0 & 1.6 & 3.2 & 1.9 & 2.9 & 3.4 & 8.2 & 9.9 \\
\hline $\mathrm{AB} 11$ & Unkno & 1. & 1.2 & 4.8 & 5.6 & 7.3 & 9.3 & 8.7 & 1.1 & 1.5 & 3.8 & 4.5 & 4.8 & 3.3 & 3.4 & 1.1 & 1.6 & 5.1 & 9.3 & 11.1 & 10.8 & 89.5 \\
\hline AB 118073* & Phosp & 2 & 3.5 & 7.9 & 9.1 & 19.6 & 21.1 & 28.1 & 2.4 & 2.4 & 4.2 & 5.2 & 6.1 & 4.3 & 5.3 & 2.2 & 3.4 & 4.9 & 7.5 & 7.1 & 13.6 & 613.3 \\
\hline AB118074* & Senescence-associated protein & 1.2 & 2.0 & 8.8 & 10.2 & 49.2 & 24.5 & 87.6 & 1.1 & 1.2 & 2.8 & 8.3 & 10.3 & 15.2 & 18.8 & 1.2 & 1.2 & 1.5 & 1.8 & 3.4 & 4.2 & 15.3 \\
\hline $\begin{array}{r}\text { AB } 118058 \\
\text { Cluster4 }\end{array}$ & Unknown & 1.6 & 1.0 & 1.6 & 3.2 & 3.1 & 5.6 & 5.2 & 1.5 & 1.1 & 1.0 & 2.5 & 3.8 & 2.4 & 3.3 & 1.4 & 1.0 & 1.4 & 2.2 & 4.1 & 6.0 & 7.1 \\
\hline $\mathrm{AB} 1$ & & & 1.4 & 3.3 & 2.8 & 4.3 & 4.2 & 7.6 & 1.3 & 1.2 & 1.5 & 1.4 & 1.3 & 1.3 & 2.1 & 1.3 & 1.4 & 1.6 & 3.0 & 2.2 & 3.2 & 4.0 \\
\hline AB118087 & Unknown & 2.2 & 3.2 & 9.4 & 3.6 & 4.7 & 4.3 & 4.5 & 1.9 & 3.9 & 2.2 & 2.8 & 1.9 & 1.8 & 1.8 & 2.1 & 6.8 & 4.1 & 5.1 & 3.3 & 5.2 & 5.6 \\
\hline
\end{tabular}


among these three $N A C$ genes, induction of $O s N A C 3$ and OsNAC4 was regulated by flagellin perception signaling, whereas OsNAC6 induction was regulated not only by the flagellin perception pathway, but also by another elicitor perception pathway. (Table 2; Fig. 3). Sequence analysis of the rice genome revealed that $O S N A C$ genes constitute a large gene family, which can be divided into several subfamilies. OsNAC3 and OsNAC4 belong to the OsNAC3 subfamily, while OsNAC6 falls into the ATAF subfamily (Kikuchi et al. 2000). Although the molecular function of NAC proteins remains unknown, plant NAC proteins are thought to be transcription factors because putative nuclear localization signals have been found in NAC proteins (Kikuchi et al. 2000). In addition, because no NAC gene has been identified thus far in bacteria, fungi, or animal genomes, NAC genes are thought to be specific to the plant genome. Further studies are sought to clarify the transcriptional control via OsNAC.

EREBPs bind GCC boxes in several PR protein gene promoters, and their transcription levels are induced by ethylene and incompatible pathogens (Durrant et al. 2000). Ethylene plays an important role in plant resistance. For example, tobacco transformed with the ethylene-resistant gene etrl-1 from Arabidopsis, conferring dominant ethylene insensitivity, showed reduced basic PR gene expression and loss of nonhost resistance to soilborne fungi (Knoester et al. 1998). Although the response of ethylene-mediated resistance is important for the rejection of Acidovorax avenae-incompatible strains, microarray and RT-PCR analysis indicate that flagellin does not play a role in this response and also predict that other elicitors are involved in rice immunity.
OsCDPK7 and $C C D 1$, which were identified as genes regulated by flagellin perception signaling using cDNA microarrays and real-time RT-PCR, possess a $\mathrm{Ca}^{2+}$-binding EF-hand domain required for their own activation (Berberich and Kusano 1997; Kawasaki et al. 2001; Takezawa 2000). Chelation of extracellular $\mathrm{Ca}^{2+}$ completely blocked the induction of $O s C D P K 7$ and $C C D 1$ expression by incompatible strain inoculation (Fig. 4), suggesting that the two gene products require elevation of intercellular free $\mathrm{Ca}^{2+}$ by influx into cultured rice cells not only for their own activation, but also for gene expression. Thus, flagellin perception would translate into elevation of intercellular $\mathrm{Ca}^{2+}$ and initiate subsequent downstream signaling events.

OsCDPK7 possesses a characteristic structure in which an $\mathrm{N}$-terminal serine/threonine protein kinase domain is fused to a carboxyterminal calmodulin-like domain containing four EF-hand calcium-binding sites (Saijo et al. 2000). Furthermore the protein motif analysis showed that the N-terminal half of OsCDPK7 contains a myristoylation site that is necessary for targeting to the membrane (Hrabak et al. 2003). Although downstream OsCDPK7-regulated processes remain largely unknown, increasing evidence has supported OsCDPK7 involvement in environmental stress signaling. The mRNA levels for OsCDPK7 increased in response to cold and salt stress, and transgenic rice plants with altered OsCDPK7 protein levels showed an altered tolerance to cold, drought, and salt stress. The extent of tolerance of these plants correlated with the level of OsCDPK7 expression: overexpression increased, whereas suppression of OsCDPK7 expression lowered the stress tolerance (Saijo et al. 2000).

Table 2. (continued from preceding page)

\begin{tabular}{|c|c|c|c|c|c|c|c|c|c|c|c|c|c|c|c|c|c|c|c|c|c|c|}
\hline \multirow[b]{2}{*}{ Accession } & \multirow[b]{2}{*}{ Putative gene identification } & \multicolumn{7}{|c|}{ N1141 } & \multicolumn{7}{|c|}{$\mathrm{Kl}$} & \multicolumn{7}{|c|}{$\Delta$ flaNli4I-2 } \\
\hline & & 0.5 & I & 2 & 3 & 4 & 5 & 6 & 0.5 & 1 & 2 & 3 & 4 & 5 & 6 & 0.5 & 1 & 2 & 3 & 4 & 5 & 6 \\
\hline Cluster4 & (Continued) & & & & & & & & & & & & & & & & & & & & & \\
\hline AB $118095^{*}$ & Unknown & 1.6 & 1.5 & 6.4 & 1.8 & 3.3 & 3.8 & 7.1 & 1.5 & 1.4 & 1.5 & 2.1 & 1.6 & 1.6 & 2.0 & 1.5 & 1.5 & 1.4 & 1.8 & 1.6 & 3.3 & 3.8 \\
\hline AB 1 18097* & Unknown & 1.8 & 1.8 & 5.3 & 2.0 & 1.9 & 3.4 & 4.0 & 1.8 & 1.6 & 1.9 & 1.9 & 1.6 & 1.9 & 2.2 & 1.9 & 2.1 & 2.1 & 2.2 & 2.1 & 3.4 & 3.2 \\
\hline AB1 18088 & Ser/Thr protein kinase & 1.0 & 1.3 & 4.4 & 2.0 & 2.8 & 2.6 & 2.8 & 1.1 & 1.3 & 2.5 & 1.4 & 1.2 & 1.0 & 1.3 & 1.0 & 2.6 & 3.8 & 4.6 & 2.8 & 4.1 & 3.6 \\
\hline AB $118091 *$ & EF-hand $\mathrm{Ca} 2+$-binding protein & 1.7 & 2.2 & 15.3 & 3.6 & 8.2 & 8.6 & 9.2 & 1.3 & 2.0 & 2.2 & 3.5 & 2.5 & 2.1 & 2.5 & 1.9 & 2.6 & 3.2 & 2.8 & 4.6 & 7.2 & 8.5 \\
\hline $\mathrm{AB} 118089^{*}$ & Unknown & 2.0 & 2.2 & 9.1 & 2.5 & 4.9 & 5.9 & 6.1 & 1.5 & 2.0 & 1.7 & 2.7 & 1.9 & 2.1 & 2.5 & 1.8 & 2.8 & 1.9 & 2.7 & 2.5 & 5.1 & 4.4 \\
\hline AB $118093 *$ & Rice EL2 & 2.8 & 4.6 & 14.1 & 4.0 & 7.1 & 9.0 & 9.1 & 2.6 & 4.5 & 3.8 & 3.2 & 2.2 & 2.0 & 3.3 & 3.1 & 4.0 & 4.5 & 4.5 & 3.4 & 4.4 & 3.6 \\
\hline AB $118094 *$ & OsCDPK7 & 1.0 & 1.2 & 6.3 & 2.6 & 5.3 & 5.4 & 7.3 & 1.0 & 1.3 & 1.6 & 2.4 & 1.8 & 1.8 & 2.2 & 1.1 & 1.4 & 1.5 & 2.0 & 1.8 & 2.0 & 2.1 \\
\hline $\mathrm{AB} 118096^{*}$ & No homology & 3.0 & 3.6 & 16.2 & 4.3 & 6.2 & 7.7 & 10.2 & 2.7 & 2.8 & 4,2 & 4.6 & 2.5 & 1.9 & 2.1 & 3.2 & 3.3 & 4.0 & 6.1 & 5.1 & 12.3 & 9.6 \\
\hline $\mathrm{AB} 118092^{*}$ & OsNAC 3 protein & 1.6 & 1.4 & 5.2 & 4.8 & 5.8 & 6.1 & 6.2 & 1.4 & 1.4 & 1.9 & 2.2 & 2.3 & 3.1 & 2.8 & 1.3 & 1.6 & 2.3 & 2.7 & 3.1 & 3.0 & 2.9 \\
\hline $\mathrm{AB} 118082^{*}$ & transcription factor ZFI & 2.1 & 3.0 & 32.0 & 6.5 & 16.0 & 12.0 & 21.3 & 1.8 & 3.8 & 3.9 & 4.3 & 4.0 & 3.3 & 3.6 & 2.0 & 4.5 & 6.9 & 8.8 & 8.4 & 11.0 & 12.2 \\
\hline AB 1 18083* & $\mathrm{Cy} /$ /His zinc finger protein & 1.5 & 1.5 & 2.7 & 1.8 & 2.5 & 2.8 & 3.6 & 1.4 & 1.5 & 1.5 & 1.7 & 1.7 & 1.9 & 2.2 & 1.4 & 1.5 & 1.4 & 1.9 & 2.0 & 2.0 & 2.2 \\
\hline AB118071* & OsNAC4 1 & 2.1 & 2.6 & 3.2 & 2.1 & 3.9 & 4.2 & 5.0 & 1.7 & 2.0 & 2.1 & 2.2 & 1.8 & 2.3 & 2.1 & 2.0 & 2.1 & 2.1 & 2.0 & 1.9 & 2.2 & 2.3 \\
\hline $\mathrm{AB} 118$ & Cytoc & 1.6 & 1.5 & 15.2 & 6.0 & 5.9 & 8.2 & 15.2 & 1.6 & 1.4 & 2.1 & 3.2 & 2.5 & 3.4 & 4.0 & 1.6 & 1.5 & 3.1 & 4.6 & 3.2 & 6.5 & 8.6 \\
\hline $\begin{array}{l}\mathrm{AB} 118098^{*} \\
\text { Cluster5 }\end{array}$ & Ric & 2.7 & 5.0 & 14.0 & 4.3 & 6.9 & 8.6 & 8.4 & 2.7 & 3.8 & 3.1 & 1.8 & 2.7 & 2.3 & 2.9 & 2.8 & 4.9 & 5.3 & 4.2 & 3.5 & 4.1 & 3.8 \\
\hline AB $118163 *$ & No homology & 3.2 & 4.2 & 16.3 & 6.1 & 15.5 & 16.2 & 19.1 & 3.1 & 5.0 & 5.9 & 4.3 & 5.2 & 3.6 & 4.0 & 3.5 & 7.3 & 6.8 & 5.2 & 7.8 & 9.8 & 10.0 \\
\hline AB1 18161* & NAC protein & 1.4 & 2.0 & 7.9 & 5.2 & 9.0 & 8.2 & 7.5 & 1.2 & 1.8 & 3.3 & 3.1 & 2.6 & 2.2 & 2.8 & 1.3 & 1.9 & 3.5 & 3.1 & 2.8 & 3.3 & 3.2 \\
\hline AB118164 & Acid 1 & 1.3 & 1.9 & 5.9 & 5.3 & 6.4 & 7.2 & 5.3 & 1.1 & 1.5 & 2.6 & 3.4 & 2.9 & 1.6 & 1.8 & 1.2 & 1.7 & 3.8 & 7.7 & 5.2 & 5.9 & 4.5 \\
\hline $\mathrm{AB} 118165^{*}$ & AT-hook DNA binding protein & 1.3 & 1.4 & 8.8 & 6.4 & 5.1 & 9.1 & 12.1 & 1.2 & 1.3 & 3.2 & 4.8 & 3.3 & 4.0 & 4.1 & 1.2 & 1.6 & 4.1 & 3.8 & 4.2 & 5.4 & 6.1 \\
\hline AB1 18167 & Unkno & 1.2 & 1.3 & 20.2 & 15.0 & 15.2 & 14.3 & 16.2 & 1.2 & 1.1 & 1.9 & 6.5 & 4.2 & 2.1 & 2.9 & 1.1 & 1.2 & 3.1 & 9.2 & 8.6 & 16.2 & 15.5 \\
\hline AB $118168 *$ & Unknown & 1.4 & 1.6 & 6.5 & 4.9 & 8.5 & 12.1 & 15.3 & 1.3 & 1.6 & 2.6 & 4.1 & 3.7 & $2 . I$ & 2.4 & 1.6 & 1.9 & 3.0 & 6.5 & 6.2 & 8.3 & 8.7 \\
\hline $\begin{array}{r}\mathrm{AB} 118162 \\
\text { Cluster6 }\end{array}$ & O. sativa myb factor & 1.9 & 1.9 & 7.5 & 3.6 & 8.1 & 6.5 & 7.2 & 1.8 & 1.7 & 1.9 & 2.1 & 2.4 & 2.2 & 2.3 & 1.8 & 1.8 & 2.5 & 4.2 & 4.9 & 6.2 & 6.9 \\
\hline AB 118170 & Se & 3.3 & 8.8 & 23.6 & 16.1 & 35.2 & 46.3 & 58.8 & 3.0 & 9.6 & 11.1 & 12.1 & 10.3 & 7.I & 8.3 & 3.5 & 16.2 & 38.2 & 24.32 & 28.3 & 55.2 & 61.2 \\
\hline $\mathrm{AB} 118171$ & Bluc copper protein & 3.6 & 10.9 & 17.2 & 7.1 & 25.5 & 16.3 & 8.6 & 3.8 & 9.5 & 8.5 & 2.8 & 2.3 & 2.1 & 1.9 & 4.0 & 16.5 & 11.3 & 32.9 & 21.0 & 26.5 & 28.8 \\
\hline AB 118169 & $\begin{array}{l}\text { Bowman-birk proteinase } \mathrm{X} \\
\text { benzoyltransferase }\end{array}$ & 1.7 & 2.6 & 10.3 & 13.2 & 25.5 & 13.3 & 6.9 & 2.0 & 2.3 & 8.2 & 6.6 & 4.6 & 2.1 & 2.3 & 1.9 & 4.2 & 13.3 & 21.8 & 22.5 & 17.2 & 6.5 \\
\hline Cluster7 & & & & & & & & & & & & & & & & & & & & & & \\
\hline AB 118174 & Beta-glucos & 1.1 & 1.2 & 1.1 & 1.3 & 1.4 & 1.1 & 1.2 & 1.1 & 1.2 & 1.2 & 1.9 & 2.4 & 2.5 & 2.8 & 1.1 & 1.1 & 1.2 & 1.1 & 1.2 & 1.0 & 1.1 \\
\hline $\mathrm{AB} 118173$ & GAST & 1.4 & 1.3 & 1.0 & 0.7 & 0.5 & 0.4 & 0.4 & 1.4 & 1.3 & 1.3 & 1.1 & 2.2 & 3.1 & 3.3 & 1.4 & 1.2 & 1.2 & 0.6 & 0.4 & 0.4 & 0.4 \\
\hline $\begin{array}{r}\text { AB } 118177 \\
\text { Cluster8 }\end{array}$ & Unknown & 1.3 & 1.2 & 1.0 & 1.1 & 1.3 & 1.2 & 1.1 & 1.3 & 1.2 & 1.0 & 1.1 & 2.0 & 3.3 & 3.5 & 1.2 & 1.3 & 1.1 & 1.0 & 0.9 & 1.0 & 0.9 \\
\hline $\mathrm{AB} 118744$ & & I.4 & 1.1 & 1.2 & 2.1 & 3.3 & 4.2 & 5.6 & 1.4 & 1.3 & 1.2 & 3.8 & 6.2 & 9.8 & 12.2 & 1.4 & 1.2 & 1.3 & 1.0 & 1.2 & 1.3 & 1.0 \\
\hline $\mathrm{AB} 118745$ & Decarboxylase $1(\mathrm{pdcl})$ & 1.1 & 1.0 & 1.6 & 4.3 & 6.8 & 9.1 & 5.3 & 1.0 & 1.3 & 1.2 & 5.1 & 10.3 & 13.6 & 13.8 & 1.0 & 1.2 & 1.1 & 2.3 & 4.8 & 7.6 & 4.3 \\
\hline
\end{tabular}


Expression of $O s C D P K 7$ also is induced rapidly by flagellin perception, suggesting that flagellin perception signaling partially overlaps with the stress signaling.

Flg22, a synthetic peptide comprising the core 22 amino acids of the conserved N-terminal region, exhibited nonspecific elicitor activity and induced defense responses in a wide range of plant species including tomato and Arabidopsis thaliana (Felix et al. 1999). In Arabidopsis, the LRR receptor kinase FLS2 recognized flg22 and induced defense responses. Interestingly, neither flg22 nor flg22-avenae (comprising flg22 of N1141 flagellin) induced any defense response in rice (Felix et al. 1999; R. Takai et al. unpublished data) and the insensitivity of rice to flg 22 was not recovered by introduction of FLS2 (Bauer et al. 2001). These data, together with induction of immune response in cultured rice cells by the incompatible flagellin, indicate that the flagellin perception signal transduction mechanism in rice differs from that for flg22 in Arabidopsis. Microarray experiments using the incompatible and compatible purified flagellin would provide important information for identification of specific perception system in cultured rice cells.

In this study, we demonstrated, using microarray and expression analyses, that the incompatible flagellin of Acidovorax avenae functions as a specific elicitor involved in the induction of several elements of the immune response and that other elicitors also are involved in induction of the rice immune response. We recently reported that incompatible flagellin induced the expression of EL2, PAL, and Cht-1, but not $L O X$. Furthermore, we showed that the incompatible flagellin of $A$. avenae is a specific elicitor in rice, but is not the only factor capable of inducing the rice defense system (Tanaka et al. 2003). The microarray results using flagellin-deficient mutants and real-time RT-PCR using purified flagellins strongly support those findings. The incompatible flagellin is likely to function in cooperation with other molecules to determine incompatibility between rice and incompatible strains of $A$. avenae. Identification of these molecules is the aim of future studies. In addition, the function of many flagellin-inducible genes identified here are still unknown. Studying the function of these genes will be important to further elucidate the molecular mechanisms of immunity in plants.

\section{MATERIALS AND METHODS}

\section{Plants and bacteria.}

Suspension cultures of rice cells, line Oc (Baba et al. 1986), were grown at $30^{\circ} \mathrm{C}$ under light irradiation. Cells were diluted in fresh medium every 7 days, and all experiments were performed 4 days after transfer.

The A. avenae $\mathrm{K} 1$ strain, isolated from rice, and N1141 strain (MAFF 301141), isolated from finger millet, were utilized as previously described (Che et al. 2000; Kadota et al. 1996). Each $A$. avenae strain was maintained at $30^{\circ} \mathrm{C}$ on Pseudomonas F agar plates (Difco Laboratories, Detroit) as described (Che et al. 1999). The $\Delta$ fla1141-2 (flagellin-deficient N1141 strain) was used as previously described (Che et al. 2000).

\section{RNA isolation and cDNA library construction.}

Two cDNA libraries (Oc-N1 and Oc-N0) were constructed from cultured rice cells (Oc line). Cells were either not inoculated (for Oc-N0) or inoculated with the incompatible N1141

Table 2. (continued from preceding page)

\begin{tabular}{|c|c|c|c|c|c|c|c|c|c|c|c|c|c|c|c|c|c|c|c|c|c|c|}
\hline \multirow[b]{2}{*}{ Accession } & \multirow[b]{2}{*}{ Putative gene identification } & \multicolumn{7}{|c|}{ N1141 } & \multicolumn{7}{|c|}{$\mathrm{K} 1$} & \multicolumn{7}{|c|}{$\Delta$ flaNi141-2 } \\
\hline & & 0.5 & 1 & 2 & 3 & 4 & 5 & 6 & 0.5 & 1 & 2 & 3 & 4 & 5 & 6 & 0.5 & 1 & 2 & 3 & 4 & 5 & 6 \\
\hline Cluster9 & & & & & & & & & & & & & & & & & & & & & & \\
\hline $\mathrm{AB} 118185$ & eta-expansin (EX) & 1.1 & 1.0 & 0.8 & 0.6 & 0.5 & 0.4 & & 1.1 & 1.0 & 1.0 & 0.9 & 1.1 & 1.6 & 1.8 & 1.1 & 1.0 & 0.7 & 0.5 & 0.5 & 0.4 & 0.4 \\
\hline & Brassinoster & & & 1.0 & 0.6 & 0.5 & & & & 1.1 & 1.2 & 0.7 & 1.4 & 1.6 & 1.7 & 1.1 & 1.0 & 1.1 & 0.7 & 0.5 & 0.4 & 0.3 \\
\hline AB 118197 & Unknown & 0.9 & 0.6 & 0.3 & 0.3 & 0.2 & 0.2 & 0.2 & 0.9 & 0.7 & 0.4 & 0.4 & 0.6 & 0.8 & 0.9 & 0.8 & 0.6 & 0.2 & 0.2 & 0.2 & 0.2 & 0.1 \\
\hline $\mathrm{AB} 118198$ & No hon & 0.6 & 0.5 & 0.4 & 0.5 & 0.5 & 0.4 & & 0.6 & 0.6 & 0.5 & 0.6 & 0.7 & 0.7 & 0.7 & 0.6 & 0.5 & 0.4 & 0.5 & 0.6 & 0.5 & 0.4 \\
\hline & & & 0.7 & 0.4 & 0.4 & 0.3 & 0.2 & & 0.6 & 0.7 & 0.5 & 0.5 & 0.5 & 0.5 & 0.5 & 0.7 & 0.6 & 0.4 & 0.4 & 0.3 & 0.2 & 0.2 \\
\hline $\mathrm{AB} 118187$ & No hom & 0.9 & 0.8 & 0.6 & 0.6 & 0.5 & 0.4 & & 0.9 & 0.9 & 1.0 & 0.8 & 1.0 & 0.6 & 0.6 & 0.9 & 0.8 & 0.8 & 0.6 & 0.6 & 0.3 & 0.3 \\
\hline & No homo & & 1.0 & 0.8 & 0.6 & 0.6 & 0.4 & & 1.1 & 1.1 & 1.0 & 0.9 & 0.8 & 0.7 & 0.7 & 1.0 & 0.9 & 1.0 & 0.9 & 0.9 & 0.7 & 0.5 \\
\hline AB 118211 & $\begin{array}{r}\text { Posttra } \\
\text { silen }\end{array}$ & 0.8 & 0.8 & 0.5 & 0.5 & 0.4 & 0.4 & 0.3 & 0.9 & 0.7 & 0.6 & 0.7 & 0.7 & 0.7 & 0.7 & 0.9 & 0.7 & 0.5 & 0.4 & 0.4 & 0.2 & 0.3 \\
\hline & & & & 0.6 & 0.7 & 0.6 & & & 0.7 & 0.7 & & & 0.9 & 0.7 & & 0.7 & 0.6 & 0.6 & 0.6 & 0.5 & 0.4 & 0.4 \\
\hline $\mathrm{AB} 1$ & & & 0.7 & 0.5 & 0.7 & 0.5 & 0.3 & & 0.8 & 0.8 & 0.8 & 0.7 & 0.8 & 0.6 & 0.6 & 0.8 & 0.7 & 0.8 & 0.6 & 0.5 & 0.4 & 0.3 \\
\hline & & & & & 0.5 & & & & 0.7 & & & & 1.0 & 0.7 & & 0.7 & 0.8 & 0.6 & 0.5 & 0.5 & 0.5 & 0.4 \\
\hline $\mathrm{AB} 118191$ & initiation factor 3 & 0.8 & 0.7 & 0.5 & 0.5 & 0.4 & 0.4 & 0.3 & 0.7 & 0.7 & 0.6 & 0.6 & 0.6 & 0.6 & 0.6 & 0.8 & 0.7 & 0.6 & 0.5 & 0.5 & 0.5 & 0.5 \\
\hline & EF-1 & & & 0.8 & 0.7 & 0.5 & 0.3 & & 1.2 & 1.3 & 1.0 & 0.9 & 0.9 & 0.7 & 0.6 & 1.2 & 1.1 & 0.9 & 0.8 & 0.6 & 0.4 & 0.3 \\
\hline & & & 1.1 & 1.1 & 1.2 & 0.9 & 0.3 & & 1.2 & 1.2 & 1.4 & 1.8 & 1.8 & 0.9 & 0.8 & 1.2 & 1.1 & 1.0 & 1.1 & 1.0 & 0.5 & 0.4 \\
\hline & & & & & 0.4 & & & & 0.6 & & & & & 0.5 & & 0.6 & & 0.4 & 0.3 & 0.3 & 0.2 & 0.2 \\
\hline $\mathrm{AB} 1$ & & 0.9 & 3.0 & 0.6 & 0.6 & 0.3 & 0.3 & & 1.0 & 1.1 & 0.9 & 0.7 & 0.7 & 0.5 & 0.4 & 1.0 & 0.8 & 0.9 & 0.5 & 0.3 & 0.2 & 0.1 \\
\hline & & & & 0.7 & 0.6 & & & & 0.8 & 0.9 & & 0.9 & 0.7 & 0.7 & 0.7 & 0.9 & 0.8 & 0.7 & 0.6 & 0.5 & 0.5 & 0.5 \\
\hline 209 & & 1.4 & 1.1 & 1.0 & 0.8 & 0.5 & 0.2 & & 1.5 & 1.8 & 1.3 & 1.0 & 0.9 & 0.7 & 0.8 & 1.5 & 1.8 & 1.2 & 0.8 & 0.7 & 0.4 & 0.2 \\
\hline $\mathrm{AB} 1$ & & 1.1 & 0.9 & 0.8 & 0.8 & 0.6 & 0.4 & 0 & 1.1 & 1.1 & 0.9 & 1.0 & 1.0 & 0.7 & 0.7 & 1.0 & 1.0 & 0.8 & 0.8 & 0.7 & 0.5 & 0.4 \\
\hline & & & 1.1 & 1.0 & 0.9 & 0.6 & 0.4 & & 1.2 & 1.2 & 1.1 & 1.0 & 0.9 & 0.8 & 0.9 & 1.2 & 1.3 & 1.0 & 0.8 & 0.7 & 0.5 & 0.4 \\
\hline $201 *$ & Plasi & 0.8 & 0.8 & 0.9 & 0.9 & 0.8 & 0.4 & & 0.8 & 1.2 & 1.2 & 1.1 & 1.0 & 0.5 & 0.5 & 0.8 & 1.1 & 1.5 & 1.4 & 1.6 & 0.9 & 0.7 \\
\hline & & & 1.1 & 0.7 & 0.7 & & & & 1.0 & 1.2 & 1.1 & 0.8 & 0.9 & 0.7 & 0.6 & 0.9 & 1.1 & 0.9 & 0.8 & 0.7 & 0.5 & 0.3 \\
\hline & & 0.7 & 0.7 & 0.5 & 0.6 & 0.5 & 0.4 & & 0.7 & 0.7 & 0.7 & 0.7 & 0.7 & 0.7 & 0.7 & 0.8 & 0.7 & 0.6 & 0.6 & 0.5 & 0.4 & 0.4 \\
\hline & & 1.0 & & 0.8 & 0.7 & 0.5 & 0.3 & & 1.1 & 1.1 & 1.0 & 0.9 & 0.9 & 0.7 & 0.6 & 1.1 & 1.1 & 0.9 & 0.7 & 0.6 & 0.4 & 0.3 \\
\hline & & & & 0.7 & 0.7 & 0.6 & 0.3 & & 1.0 & 1.0 & 0.9 & 0.8 & 0.7 & 0.8 & 0.7 & 1.0 & 1.0 & 0.8 & 0.6 & 0.6 & 0.5 & 0.4 \\
\hline $\mathrm{AB} 118210$ & Elong & 0.9 & 0.7 & 0.6 & 0.7 & 0.6 & 0.4 & 0.4 & 0.9 & 0.8 & 0.9 & 0.8 & 1.0 & 0.9 & 0.9 & 0.9 & 0.8 & 0.8 & 0.6 & 0.6 & 0.4 & 0.3 \\
\hline $\mathrm{AB} 118214$ & & & 1.1 & 0.9 & 0.6 & 0.5 & 0.3 & & 1.2 & 1.1 & 1.0 & 0.9 & 0.8 & 0.6 & 0.6 & 1.2 & 1.1 & 0.9 & 0.7 & 0.6 & 0.4 & 0.4 \\
\hline $\mathrm{AB} 118178$ & & 0.9 & 0.8 & 0.7 & 0.7 & 0.6 & 0.4 & 0.3 & 0.9 & 0.9 & 1.0 & 0.8 & 0.8 & 0.6 & 0.5 & 1.0 & 0.8 & 1.0 & 0.6 & 0.6 & 0.4 & 0.3 \\
\hline & & 1.0 & 0.8 & 0.6 & 0.6 & 0.5 & 0.3 & & 1.0 & 0.9 & 0.7 & 0.6 & 0.8 & 0.7 & 0.7 & 1.0 & 0.8 & 0.6 & 0.4 & 0.4 & 0.3 & 0.2 \\
\hline $\mathrm{AB} 118183$ & & & 1.0 & 0.8 & 0.6 & 0.7 & 0.4 & 0.4 & 1.2 & 1.1 & 0.9 & 0.9 & 1.0 & 1.0 & 1.0 & 1.2 & 1.1 & 0.6 & 0.6 & 0.5 & 0.5 & 0.5 \\
\hline & & 0.8 & 0.8 & 0.7 & 0.7 & 0.5 & 0.4 & 0.4 & 0.9 & 0.8 & 0.7 & 0.8 & 0.7 & 0.6 & 0.6 & 0.9 & 0.7 & 0.6 & 0.6 & 0.5 & 0.4 & 0.4 \\
\hline $\mathrm{AB} 118184$ & Heat shock protein 80 & 0.6 & 0.6 & 0.5 & 0.5 & 0.4 & 0.3 & 0.3 & 0.6 & 0.7 & 0.6 & 0.5 & 0.6 & 0.5 & 0.5 & 0.6 & 0.6 & 0.5 & 0.4 & 0.4 & 0.3 & 0.3 \\
\hline
\end{tabular}


strain $\left(10^{8} \mathrm{CFU} \mathrm{ml} \mathrm{m}^{-1}\right)$ (for Oc-N1) at $30^{\circ} \mathrm{C}$ for $1 \mathrm{~h}$. Total RNA was isolated from cultured rice cells using ISOGEN (Nippongene, Tokyo). Poly (A)+ RNA was purified using the Oligotex-dT30 mRNA Purification Kit (Takara, Kyoto, Japan). The cDNA library was constructed with a ZAPII-cDNA synthesis kit (Stratagene, La Jolla, CA, U.S.A.) according to the manufacturer's instructions. In vivo excision of pBluescript $\mathrm{SK}+$ plasmids was performed in XL1-blue MRF Escherichia coli. Approximately 5,000 inserts cloned into pBluescript SK+ were sequenced utilizing an M13 reverse primer with a DNA sequencer (ABI PRISM 3700 DNA Analyzer; PerkinElmer, Foster City, CA, U.S.A.). Sequence homologies were examined with the GenBank/EMBL database using the FASTA program.

\section{Preparation of cDNA microarrays.}

Sequence analysis of cDNA clones identified 3,353 unique clones. Inserts of unique cDNA clones were amplified by PCR for 35 cycles using primers complementary to vector sequences flanking both sides of the cDNA insert (5'-TCATTAG GCACCCCAGGCTTTACAC-3', 5'-GTAATACGACTCACTA TAGGGC-3'). PCR products were electrophoresed on a $1.5 \%$ agarose gel to confirm amplification quality and quantity. DNA was precipitated in ethanol, resuspended in $\mathrm{H}_{2} \mathrm{O}$, and then crosslinking reagent was added (Amersham Biotech, Piscataway, NJ, U.S.A.).

PCR products were arrayed from 384-well microtiter plates onto T7 star microslide glass (Amersham Biotech) using a microarray spotter (GenIII Microarray Spotter, Amersham Biotech).

\section{Synthesis of fluorescently labeled cDNA.}

Following incubation with each bacterial strain or incubation without bacteria, cultured rice cells were ground in liquid nitrogen. Total RNA was extracted with ISOGEN (Nippongene, Tokyo) and mRNA was purified using the OligotexdT30 mRNA Purification Kit (Takara, Kyoto, Japan). Cy3- or Cy5-labeled cDNA probes were prepared with a CyScribe first-strand cDNA labeling kit (Amersham Biotech) according to the manufacturer's protocol. Labeled probes were treated with $2 \mu \mathrm{l}$ of $2.5 \mathrm{M} \mathrm{NaOH}$. After incubating at $37^{\circ} \mathrm{C}$ for $15 \mathrm{~min}, 10 \mu \mathrm{l}$ of $2 \mathrm{M}$ HEPES was added to the probe solution for neutralization. Synthesized probes were purified fur- ther by a CyScribe GFX Purification Kit (Amersham Biotech) according to the manufacturer's protocol. A total of 250 $\mu \mathrm{l}$ of distilled water was added to the purified probe solutions, which then were poured onto Microcon YM-30 columns (Millipore, Bedford, MA, U.S.A.). After centrifugation for $6 \mathrm{~min}$ at $4,000 \times g$, the flow-through was discarded, 250 $\mu \mathrm{l}$ of distilled water was added, and the samples were spun again. After this was repeated three times, the probe retained by the Microcon was significantly brighter than the flowthrough product. Probes were collected by inverting the filter and spinning for $1 \mathrm{~min}$. Probe samples were denatured by placing them in a $95^{\circ} \mathrm{C}$ block incubator for $3 \mathrm{~min}$, after which they were left at room temperature for $10 \mathrm{~min}$ and used for hybridization.

\section{Microarray hybridization and scanning.}

In all, $0.5 \mu \mathrm{l}$ of $10 \%$ sodium dodecyl sulfate (SDS) was added to $25 \mu \mathrm{l}$ of each labeled probe sample, and samples were centrifuged at $15,000 \times g$ for 5 min to remove any particulate matter. The probes were placed onto the center of the array to avoid forming bubbles. A cover slip was placed over the entire array surface, also to avoid bubble formation. A total of $7 \mathrm{ml}$ of $5 \times \mathrm{SSC}(1 \times \mathrm{SSC}$ is $0.15 \mathrm{M} \mathrm{NaCl}$ plus $0.015 \mathrm{M}$ sodium citrate) was poured onto five paper towels and placed on a separate part of the slide to provide humidity in the hybridization cassette. Slides were placed in a sealed hybridization cassette and incubated in a hybridization incubator (Taitec, Saitama, Japan) at $65^{\circ} \mathrm{C}$ for 12 to $14 \mathrm{~h}$. After hybridization, slides were soaked in washing solution $1(0.1 \times$ SSC and $0.02 \%$ SDS), and were tilted down to remove the cover grass. The slides were placed into slide racks and plunged up and down three times in washing solution 1 at $55^{\circ} \mathrm{C}$ for $10 \mathrm{~min}$. The slide racks were transferred to washing solution $2(0.2 \times \mathrm{SSC}$ and $0.02 \% \mathrm{SDS})$ at $55^{\circ} \mathrm{C}$ for $10 \mathrm{~min}$. The slides were plunged up and down in $0.2 \times \mathrm{SSC}$ for $10 \mathrm{~min}$ at room temperature to remove SDS. After repeating this washing procedure in $0.2 \times$ SSC three times, slides were washed in distilled water for $1 \mathrm{~min}$, spun at $1,500 \times g$ for 5 min, and dried in a dry box.

Microarrays were scanned with a scanning laser microscope, model ScanArray4000XL (GSI Lumonics, Billerica, MA, U.S.A.). Separate images were acquired for each fluor at a resolution of $10 \mu \mathrm{m}$ per pixel.
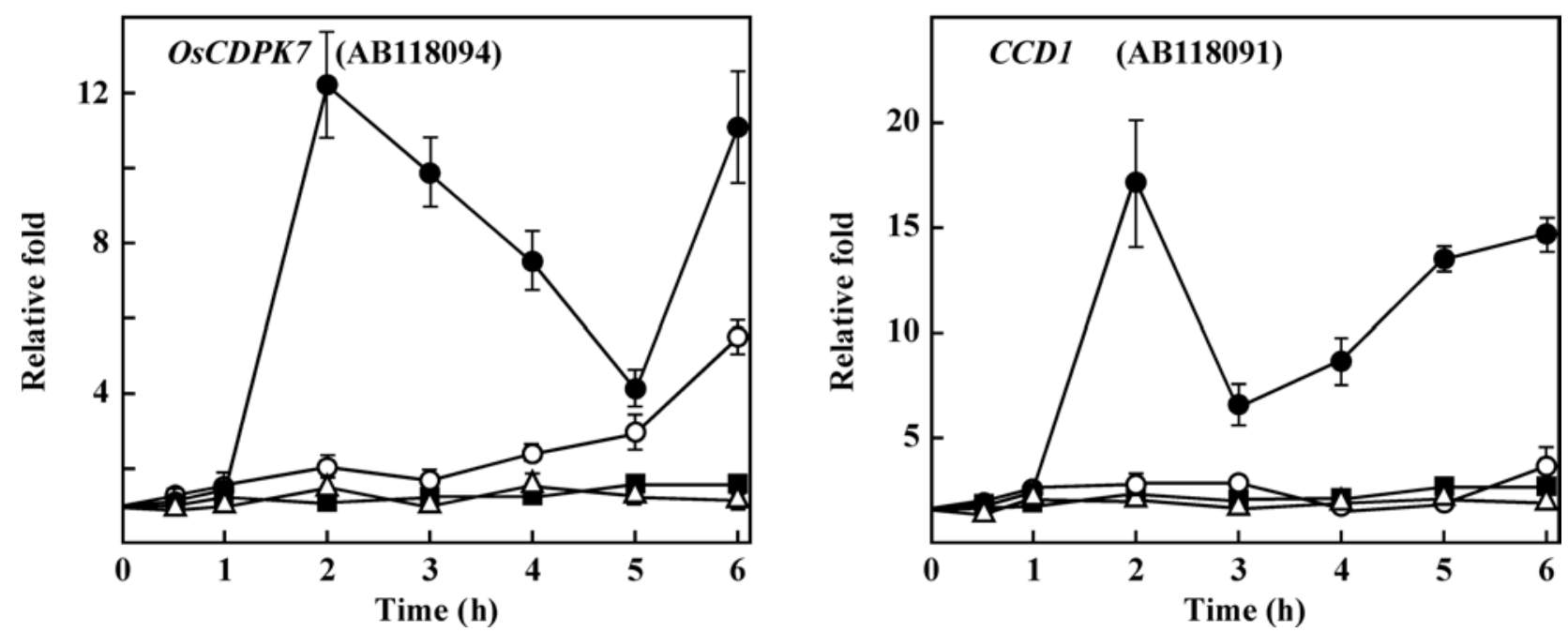

Fig. 4. Effects of EGTA on induction of OsCDPK7 (AB118094) and CCD1 (AB118091). The amount of each mRNA was calculated from the threshold point located in the log-linear range of reverse-transcription polymerase chain reaction. Standard samples with known template amounts were used for quantification of each mRNA. Solid circles, N1141 inoculation; open circles, $\Delta$ fla1141-2 (flagellin-deficient N1141 strain) inoculation; solid squares, K1 inoculation; open triangles, $1 \mathrm{mM}$ EGTA (final concentration) plus N1141 inoculation The $y$ axis represents fold change relative to the amount of mRNA in water-treated cultured rice cells. Bars indicate standard deviation of mean of three experiments. 

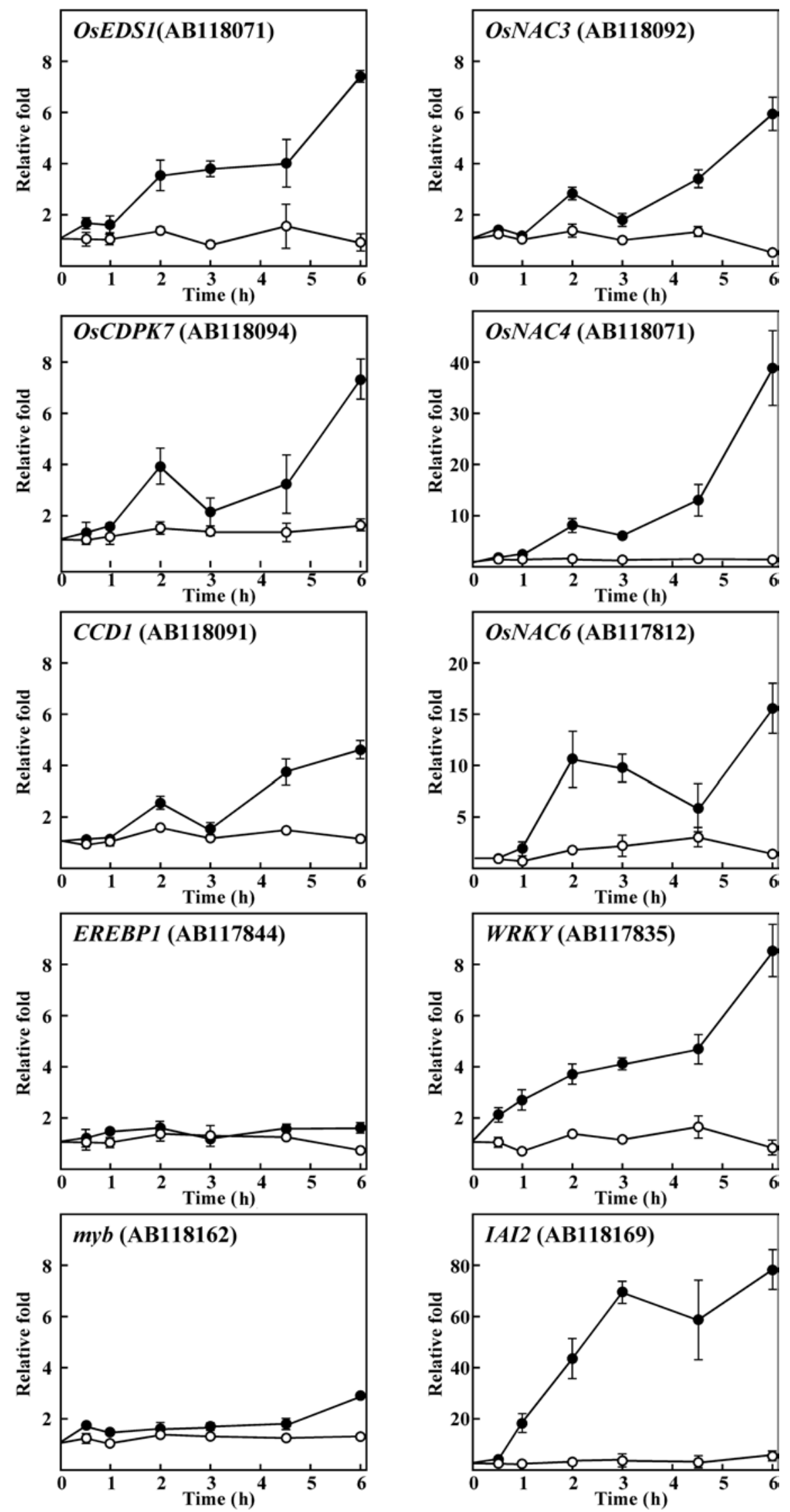

Fig. 5. Effects of purified flagellins on expression of OsEDS1 (AB118071), OsCDPK7 (AB118094), CCD1 (AB118091), EREBP1 (AB117844), OsNAC3 (AB118092), OsNAC4 (AB118071), OsNAC6 (AB117812), WRKY (AB117835), myb (AB118162), and IAI2 (AB118169) using real-time reversetranscription polymerase chain reaction (RT-PCR). The amount of each mRNA was calculated from the threshold point located in the log-linear range of RTPCR. Standard samples with known template amounts were used for quantification of each mRNA Solid circles, N1141 flagellin treatment; open circles, K1 flagellin treatment The $y$ axis represents fold change relative to the amount of mRNA in water-treated cultured rice cells. Bars indicate standard deviation of mean of three experiments. 


\section{Data analysis.}

For microarray data analysis, we used ImaGene version 5.1 (BioDiscovery, Los Angeles) and GeneSpring 5.0 (Silicon Genetics, Redwood, CA, U.S.A.). Local background was subtracted from the value of each spot on the array. Spots covered by dust particles, missing spots, spots with low signal intensity, and spots in high background areas were flagged as candidates for exclusion after further analysis. Normalization between the $\mathrm{Cy} 3$ and $\mathrm{Cy} 5$ fluorescent dye emission channels was achieved by calculating the ratio between total $\mathrm{Cy} 3$ signal from all spots in relation to total Cy5 signal from all spots (Hardwick et al. 1999).

\section{Real time RT-PCR.}

Expression profiles of selected genes were analyzed by realtime RT-PCR analysis using the QuantiTect SYBR Green RTPCR kit (Qiagen, Hilden, Germany). Cultured rice cells was inoculated with $\mathrm{N} 1141$ or $\mathrm{K} 1\left(10^{8} \mathrm{CFU} \mathrm{ml} l^{-1}\right)$, or incubated with purified N1141 flagellin or K1 flagellin $\left(15 \mu \mathrm{g} \mathrm{ml}^{-1}\right)$ that was purified from N1141 or K1 strains by a previously described method (Tanaka et al. 2003). Ten nanograms of total RNA prepared from N1141- or K1-inoculated or N1141 or K1 flagellin-incubated cultured rice cells and the specific primer sets targeting $150 \mathrm{bp}$ of each gene were used. Real-time RTPCR was performed according to the manufacturer's protocol (QuantiTect SYBR Green RT-PCR kit; Qiagen) and the reaction was monitored using the ABI PRISM 7700 sequence detection system (Perkin-Elmer). Fluorescence data produced sigmoidal-shaped amplification plots, in which the number of cycles was plotted against fluorescence. Quantification of each mRNA was calculated from threshold points located in the log-linear range of RT-PCR. Standard samples with known template amounts were used for quantification of PCR products

\section{ACKNOWLEDGMENTS}

We would like to thank H. Sato and E. Okamoto for preparation of rice cDNA microarray. This work was supported in part by Grants-in-Aid for scientific research on priority area (A) (Molecular Mechanisms of PlantPathogenic Microbe Interaction); Scientific Research (B) (15380084) from the Ministry of Education, Culture, Sports, Science, and Technology; and Research for the Future Program from the Japan Society for the Promotion of Science (JSPS-RFTF00L01604).

\section{LITERATURE CITED}

Aderem, A., and Ulevitch, R. J. 2000. Toll-like receptors in the induction of the innate immune response. Nature 406:782-787.

Akimoto-Tomiyama, C., Sakata, K., Yazaki, J., Nakamura, K., Fujii, F., Shimbo, K., Yamamoto, K., Sasaki, T., Kishimoto, N., Kikuchi, S., Shibuya, N., and Minami, E. 2003. Rice gene expression in response to $\mathrm{N}$-acetylchitooligosaccharide elicitor: Comprehensive analysis by DNA microarray with randomly selected ESTs. Plant Mol. Biol. 52:537-551.

Baba, A., Hasezawa, S., and Syono, K. 1986. Cultivation of rice protoplasts and their transformation mediated by Agrobacterium spheroplasts. Plant Cell Physiol. 27:463-472.

Bauer, Z., Gomez-Gomez, L., Boller, T., and Felix, G. 2001. Sensitivity of different ecotypes and mutants of Arabidopsis thaliana toward the bacterial elicitor flagellin correlates with the presence of receptorbinding sites. J. Biol. Chem. 276:45669-45676.

Berberich, T., and Kusano, T. 1997. Cycloheximide induces a subset of low temperature-inducible genes in maize. Mol. Gen. Genet. 254:275283.

Boller, T. 1995. Chemoperception of microbial signals in plant cells. Annu. Rev. Plant Physiol. Plant Mol. Biol. 46:189-214.

Bolwell, G. P., Butt, V. S., Davies, D. R., and Zimmerlin, A. 1995. The origin of the oxidative burst in plants. Free Radic. Res. 23:517-532.

Che, F. S., Entani, T., Marumoto, T., Taniguchi, M., Takayama, S., and Isogai, A. 2001. Identification of novel genes differentially expressed in compatible and incompatible interactions between rice and Pseudomonas avenae. Plant Sci. 162:449-458.
Che, F. S., Iwano, M., Tanaka, N., Takayama, S., Minami, E., Shibuya, N., Kadota, I., and Isogai, A. 1999. Biochemical and morphological features of rice cell death induced by Pseudomonas avenae. Plant Cell Physiol. 40:1036-1045.

Che, F. S., Nakajima, Y., Tanaka, N., Iwano, M., Yoshida, T., Takayama, S., Kadota, I., and Isogai, A. 2000. Flagellin from an incompatible strain of Pseudomonas avenae induces a resistance response in cultured rice cells. J. Biol. Chem. 275:32347-32356.

Collinge, M., and Boller, T. 2001. Differential induction of two potato genes Stprx 2 and StNAC in response to infection by Phytophthora infestans and to wounding. Plant Mol. Biol. 46:521-529.

Dixon, R. A., Harrison, M. J., and Lamb, C. J. 1994. Early events in the activation of plant defense responses. Annu. Rev. Phytopathol. 32:479501.

Dixon, R. A., and Paiva, N. L. 1995. Stress-induced phenylpropanoid metabolism. Plant Cell 7:1085-1097.

Durrant, W. E., Rowland, O., Piedras, P., Hammond-Kosack, K. E., and Jones, J. D. 2000. cDNA-AFLP reveals a striking overlap in racespecific resistance and wound response gene expression profiles. Plant Cell 12:963-977.

Duval, M., Hsieh, T. F., Kim, S. Y., and Thomas, T. L. 2002. Molecular characterization of AtNAM: A member of the Arabidopsis NAC domain superfamily. Plant Mol. Biol. 50:237-248.

Eisen, M. B., and Brown, P. O. 1999. DNA arrays for analysis of gene expression. Methods Enzymol. 303:179-205.

Falk, A., Feys, B. J., Frost, L. N., Jones, J. D., Daniels, M. J., and Parker, J. E. 1999. EDS1 an essential component of R gene-mediated disease resistance in Arabidopsis has homology to eukaryotic lipases. Proc. Natl. Acad. Sci. U.S.A. 96:3292-3297.

Felix, G., Duran, J. D., Volko, S., and Boller, T. 1999. Plants have a sensitive perception system for the most conserved domain of bacterial flagellin. Plant J. 18:265-276.

Greenberg, J. T. 1997. Programmed cell death in plant-pathogen interactions. Annu. Rev. Plant Physiol. Plant Mol. Biol. 48:525-545.

Hardwick, J. S., Kuruvilla, F. G., Tong, J. K., Shamji, A. F., and Schreiber, S. L. 1999. Rapamycin-modulated transcription defines the subset of nutrient-sensitive signaling pathways directly controlled by the Tor proteins. Proc. Natl. Acad. Sci .U.S.A. 96:14866-14870.

Heath, M. C. 2000. Non-host resistance and non-specific plant defenses. Curr. Opin. Plant Biol. 3:315-319.

Hrabak, E. M., Chan, C. W., Gribskov, M., Harper, J. F., Choi, J. H., Halford, N., Kudla, J., Luan, S., Nimmo, H. G., Sussman, M. R., Thomas, M., Walker-Simmons, K., Zhu, J. K., and Harmon, A. C. 2003. The Arabidopsis CDPK-SnRK superfamily of protein kinases. Plant Physiol. 132:666-680.

Ito, T., Kito, K., Adati, N., Mitsui, Y., Hagiwara, H., and Sakaki, Y. 1994. Fluorescent differential display: Arbitrarily primed RT-PCR fingerprinting on an automated DNA sequencer. FEBS (Fed. Eur. Biol. Soc.) Lett. 351:231-236.

Iwano, M., Che, F. S., Goto, K., Tanaka, N., Takayama, and S., Isogai, A. 2002. Electron microscopic analysis of the $\mathrm{H}_{2} \mathrm{O}_{2}$ accumulation preceding hypersensitive cell death induced by an incompatible strain of Pseudomonas avenae in cultured rice cells. Mol. Plant Pathol. 3:1-8.

Kadota, I., Mizuno, A., and Nishiyama, K. 1996. Detection of a protein specific to the strain of Pseudomonas avenae Manns 1909 pathogenic to rice. Ann. Phytopathol. Soc. Jpn. 62:425-428.

Kadota, I., Ohuchi, and A., and Nishiyama, K. 1991. Serological properties and specificity of Pseudomonas avenae Manns 1909 the causal agent of bacterial brown stripe of rice. Ann. Phytopathol. Soc. Jpn. 57:268-273.

Kawasaki, S., Borchert, C., Deyholos, M., Wang, H., Brazille, S., Kawai, K., Galbraith, D., and Bohnert, H. J. 2001. Gene expression profiles during the initial phase of salt stress in rice. Plant Cell 13:889-905.

Keller, H., Pamboukdjian, N., Ponchet, M., Poupet, A., Delon, R., Verrier, J. L., Roby, D., and Ricci, P. 1999. Pathogen-induced elicitin production in transgenic tobacco generates a hypersensitive response and nonspecific disease resistance. Plant Cell 11:223-235.

Kikuchi, K., Ueguchi-Tanaka, M., Yoshida, K. T., Nagato, Y., Matsusoka, M., and Hirano. H. Y. 2000. Molecular analysis of the NAC gene family in rice. Mol. Gen. Genet. 262:1047-1051.

Kim, C. Y., Lee, S. H., Park, H. C., Bae, C. G., Cheong, Y. H., Choi, Y. J., Han, C., Lee, S. Y., Lim, C. O., and Cho, M. J. 2000. Identification of rice blast fungal elicitor-responsive genes by differential display analysis. Mol. Plant-Microbe. Interact. 13:470-474.

Knoester, M., van Loon, L. C., van den Heuvel, J., Hennig, J., Bol, J. F. and Linthorst, H. J. M. 1998. Ethylene-insensitive tobacco lacks nonhost resistance against soil-borne fungi. Proc. Natl. Acad. Sci. U.S.A. 95:1933-1937.

Lamb, C., and Dixon, R. A. 1997. The oxidative burst in plant disease response. Annu. Rev. Plant Physiol. Plant Mol. Biol. 48:251-275. 
Park, J. M., Park, C. J., Lee, S. B., Ham, B. K., Shin, R., and Paek, K. H. 2001. Overexpression of the tobacco Tsil gene encoding an EREBP/ AP2-type transcription factor enhances resistance against pathogen attack and osmotic stress in tobacco. Plant Cell 13:1035-1046.

Reymond, P., Weber, H., Damond, M., and Farmer, E. E. 2000. Differential gene expression in response to mechanical wounding and insect feeding in Arabidopsis. Plant Cell 12:707-720.

Rushton, P. J., and Somssich, I. E. 1998. Transcriptional control of plant genes responsive to pathogens. Curr. Opin. Plant Biol. 1:311-315.

Saijo, Y., Hata, S., Kyozuka, J., Shimamoto, K., and Izui, K. 2000. Over-expression of a single $\mathrm{Ca}^{2+}$-dependent protein kinase confers both cold and salt/drought tolerance on rice plants. Plant J. 23:319327.

Schena, M., Shalon, D., Davis, R. W., and Brown, P. O. 1995. Quantitative monitoring of gene expression patterns with a complementary DNA microarray. Science 270:467-470.

Takezawa, D. 2000. A rapid induction by elicitors of the mRNA encoding CCD-1 a $14 \mathrm{kDa} \mathrm{Ca}{ }^{2+}$-binding protein in wheat cultured cells. Plant Mol. Biol. 42:807-817.

Tanaka, N., Che, F. S., Watanabe, N., Fujiwara, S., Takayama, S., and Isogai, A. 2003. Flagellin from an incompatible strain of Acidovorax avenae mediates $\mathrm{H}_{2} \mathrm{O}_{2}$ generation accompanying hypersensitive cell death and expression of PAL Cht-1 and PBZl but not of Lox in rice. Mol. Plant-Microbe. Interact. 16:422-428.

Tanaka, N., Nakajima, Y., Kaneda, T., Takayama, S., Che, F. S., and Isogai, A. 2001. DNA laddering during hypersensitive cell death in cultured rice cells induced by an incompatible strain of Pseudomonas avenae. Plant Biotechnol. 18:295-299.

Yang, H. J., Shen, H., Chen, L., Xing, Y. Y., Wang, Z. Y., Zhang, J. L., and Hong, M. M. 2002. The OsEBP-89 gene of rice encodes a putative EREBP transcription factor and is temporally expressed in developing endosperm and intercalary meristem. Plant Mol. Biol. 50:379-391.

Yang, Y., Shah, J., and Klessig, D. F. 1997. Signal perception and transduction in plant defense responses. Genes Dev. 11:1621-1639.

Zhu, Q., Dabi, T., Beeche, A., Yamamoto, R., Lawton, M., and Lamb, C. 1995. Cloning and properties of rice gene encoding phenylalanine ammonia-lyase. Plant Mol. Biol. 29:535-550.

\section{AUTHOR-RECOMMENDED INTERNET RESOURCES}

MIPS Arabidopsis thaliana database: mips.gsf.de/proj/thal/db MOTIF sequence motif search server: motif.genome.ad.jp 